\title{
MAKING MEANing: TOWARDS A NARRATIVE THEORY OF STATUTORY INTERPRETATION AND JUDICIAL JUSTIFICATION
}

\author{
RANDY D. GORDON*
}

\begin{abstract}
The act of judging is complex involving finding facts, interpreting law, and then deciding a particular dispute. But these are not discreet functions: they bleed into one another and are thus interdependent. This article aims to reveal - at least in part—how judges approach this process. To do so, I look at three sets of civil RICO cases that align and diverge from civil antitrust precedents. I then posit that the judges in these cases base their decisions on assumptions about RICO's purpose. These assumptions, though often tacit and therefore not subject to direct observation, are nonetheless sometimes revealed when a judge narrates legislative history. I conclude by remarking that a narrative theory of interpretation and justification may have universal relevance.
\end{abstract}

Key words: Racketeer Influenced and Corrupt Organizations Act, RICO, Sherman Act, Clayton Act, antitrust extraterritoriality, legal theory, interpretation, justification, narrative, narrativity, history, legislative history, statutory purpose, legislative intent.

\section{INTRODUCTION}

Statutes that are open textured (like the Sherman Act) or vague (like the Racketeer Influenced and Corrupt Organizations Act (RICO)) present complicated questions of interpretation and application. RICO is especially difficult because it has a multi-layered structure threaded with (sometimes defined) concepts invented for this statute alone. To state a civil RICO claim, a plaintiff must show that he was injured "by reason of" a criminal RICO violation, which entails pleading such a violation, and in turn requiring him to identify the predicate commission of certain specified crimes (e.g., mail or wire fraud) and to satisfy certain defined terms (e.g., pleading the existence

\footnotetext{
*Ph.D., Edinburgh; LL.M., Columbia; J.D., Washburn; Ph.D., M.A., B.A., Kansas. Executive Professor, Texas A\&M School of Law and Department of History (joint appointment). The author wishes to thank Megan Reed, his research assistant and a student at Texas A\&M School of Law, for her considerable contribution to the authorities cited below. The views expressed in this article are the author's alone and do not necessarily represent those of Texas A\&M or his clients.
} 
of an "enterprise"). ${ }^{1}$ This is ideal land upon which to lay out a multitude of interpretive tracks, which, as Karl Llewellyn once remarked, "lead in happily variant directions."

\section{INTERPRETATIVE APPROACHED TO RICO}

\section{A. Some RICO Realism}

I do not intend the reference to Llewellyn to signal that my aim is to make a full- blown Realist critique of statutory interpretation within a set of RICO cases. But a couple of that group's insights take us a fair way towards understanding how and why certain decisions are made the way that they are. First, RICO, with its difficult structure and "fuzzily" defined terms, is a fitting exemplar of Jerome Frank's observation that "the popular notion of the possibilities of legal exactness is based on a misconception. The law always has been, is now, will ever continue to be, largely vague and variable." 3 Second, under analytical and interpretive pressure, decisions reveal a process of "rationalization" at work: viz., written opinions do not mirror the process giving rise to them but rather show only "trained lawyers' arguments made by the judges (after the decision has been reached), intended to make the decision seem plausible, legally decent, legally right, to make it seem, indeed, legally inevitable[.]"'4

\footnotetext{
${ }^{1} 18$ U.S.C. § 1964. I've previously discussed RICO's structure, application and history in greater detail than I will in this article. For a fuller analysis of matters merely summarized or excerpted below, see my four other RICO articles: Randy D. Gordon, Of Gangs and Gaggles: Can a Corporation be Part of an Association-inFact RICO Enterprise? Linguistic, Historical, and Rhetorical Perspectives, 16 U. PA. J. BUS. L. 973 (2014) [hereinafter Gordon, Gangs and Gaggles]; Randy D. Gordon, Clarity and Confusion: RICO's Recent Trips to the United States Supreme Court, 85 TUL. L. REV. 677 (2011) [hereinafter Gordon, Clarity and Confusion]; Randy D. Gordon, Crimes that Count Twice: A Reexamination of RICO's Nexus Requirements under 18 U.S.C $\$ \$ 1962$ (c) and 1964(c), 32 VT. L. REV. 171 (2007) [hereinafter Gordon, Crimes that Count Twice]; Randy D. Gordon, Rethinking Civil RICO: The Vexing Problem of Causation in Fraud-Based Claims under 18 U.S.C. $\S 1962(c), 39$ U.S.F.L. REV. 319 (2005) [hereinafter Gordon, Rethinking Civil $\mathrm{RICO}$.

${ }^{2}$ Karl N. Llewellyn, The Common Law Tradition: Deciding Appeals 373 (1960).

3 Jerome Frank, LAW AND THE Modern Mind 6 (1930); Lawrence M. Solan,
} Statutory Inflation and Institutional Choice, 44 WM. \& MARY L. REV. 2209, 225660 (2003) (discussing how " $[\mathrm{t}]$ he courts have made it easy for federal prosecutors to use the mail fraud statute to obtain federal jurisdiction over 'garden-variety frauds,' but extremely difficult for plaintiffs to use the mail fraud statute to sue for treble damages over those same 'garden-variety frauds"').

${ }^{4}$ Karl N. Llewellyn, Some Realism about Realism-Responding to Dean Pound, 44 HARV. L. REV. 1222, 1238-39 (1931). 
As Brian Leiter explains, "all the Realists endorsed what may be called 'the Core Claim' of Realism: in deciding cases, judges respond primarily to the stimulus of the facts of the case, rather than to legal rules and reasons." In reacting to the facts, "sociological" Realists (like Llewellyn) thought "that various 'social' forces must operate upon judges to force them to respond to facts in similar, and predictable ways." This does not mean that statutory interpretation is purely an ad hoc facts-only exercise: "If a statute is to make sense, it must be read in the light of some assumed purpose. A statute merely declaring a rule, with no purpose or objective, is nonsense." 7 So, in one sense, our project here is to construct an account of how a court goes about the task of discerning a statute's "purpose or objective," and how "social forces" figure into the process. ${ }^{8}$

\section{B. An Interpretive Toolkit for RICO}

A judge facing an interpretive question has an array of tools at his or her disposal. In recommending one approach over another, I've found it helpful first to sort the candidates into the categories that Neil MacCormick has suggested: ${ }^{9}$ linguistic, systemic, and teleological-evaluative arguments (all of which can be suffused with intentional arguments). ${ }^{10}$ Linguistic arguments often present appeal to "plain meaning" or "ordinary language." 11 Systemic arguments evaluate particular text-bites in a larger context, perhaps in other sections of a statute, an entire statutory title, or other aspects of a whole legal system. ${ }^{12}$ Teleological-evaluative arguments focus on the consequences of rival interpretations and try to match the preferred interpretation with particular salutary social ends or values. ${ }^{13}$ And, as one might suspect, each of these techniques necessarily invokes (or claims to demonstrate) the "intent" or "purpose" of the legislature in choosing particular words, leaving out particular words, and so forth. ${ }^{14}$

\footnotetext{
${ }^{5}$ Brian Leiter, American Legal Realism, in THE BLACKWELl GUIDE TO THE PhILOSOPHY OF LAW AND LEGAL THEORY 50, 52 (Martin P. Golding \& William A. Edmundson, eds., 2005).

${ }^{6} I d$. at 54. By contract, Leiter identifies Frank as an "idiosyncratic" Realist, who believed that "what determines the judge's response to the facts of a particular case are idiosyncratic facts about the psychology or personality of that individual judge."

${ }^{7}$ LLEEWLLYN, supra note 2, at 374.

${ }^{8}$ Id.; Leiter, supra note 5, at 54.

${ }^{9}$ See Gordon, Gangs and Gaggles, supra note 1, at 997.

${ }^{10}$ NeIL MACCORMICK, RHETORIC AND THE RULE OF LAW: A THEORY OF LEGAL REASONING 124-25 (2005).

${ }^{11} \mathrm{Id}$. at 125 .

${ }^{12} \mathrm{Id}$. at 127-32. MacCormick sub-categorizes systemic arguments in terms of (1) contextual harmonization, (2) precedent, (3) analogy, (4) conceptual, (5) general principles, and (6) history.

${ }^{13} I d$. at $132-37$.

${ }^{14} \mathrm{Id}$. at 125 .
} 


\section{Linguistic Arguments}

Because we can never be certain what a legislature meant, we are left with what it said. This does not mean that judges are blinkered to intentionalist appeals and at an interpretive remove from their own social constructions: for as MacCormick suggests, even linguistic arguments and justifications can be infused with intentionalist notes. So let's begin (we'll elaborate later) with some baseline "intent" assumptions that everyone can agree on. Congress's declared purpose in passing the Organized Crime Control Act of 1970 - of which RICO is one part-was "to seek the eradication of organized crime in the United States by strengthening the legal tools in the evidence-gathering process, by establishing new penal prohibitions, and by providing enhanced sanctions and new remedies to deal with the unlawful activities of those engaged in organized crime." 15 Together, the eleven titles of the Act form these "legal tools"; three of them, Titles VIII (interstate gambling), IX (RICO), and XI (distribution of explosives), created new substantive offenses. ${ }^{16}$ The point to be taken here is that Congress didn't just outlaw "organized crime" (in fact the phrase remains undefined in the Act); rather, it sought to craft procedures and remedies to correct "defects" in existing law that allowed organized criminals to evade prosecution. RICO was intended to remedy (at least) one of these defects.

There is no dispute that "the major purpose of Title IX is to address the infiltration of legitimate businesses by organized crime."17 "Major," of course, doesn't mean "only," so the big question remaining is, what are the other purposes? ${ }^{18}$ The Supreme Court's first significant step towards an

\footnotetext{
${ }^{15}$ Organized Crime Control Act of 1970, Pub. L. No. 91-452, 84 Stat. 922, 923 (1970).

${ }^{16} I d$. at $\S \S 803(\mathrm{a}), 901(\mathrm{a}), 1102(\mathrm{a})$.

${ }^{17}$ United States v. Turkette, 452 U.S. 576, 591 (1981).

${ }^{18}$ Justice Thomas's dissent in Anza v. Ideal Steel Supply Corp. fairly represents a major strain of concern, especially along RICO's civil dimension:

Judicial sentiment that civil RICO's evolution is undesirable is widespread. Numerous justices have expressed dissatisfaction with either the breadth of RICO's application, Sedima, S.P.R.L.v. Imrex Co., 473 U.S. 479, 501 (1985) (Marshall, J., joined by Brennan, Blackmun, and Powell, JJ., dissenting) ("The Court's interpretation of the civil RICO statute quite simply revolutionizes private litigation; it validates the federalization of broad areas of state common law of frauds, and it approves the displacement of well- established federal remedial provisions .... . [T] here is no indication that Congress even considered, much less approved, the scheme that the Court today defines"), or its general vagueness at outlining the conduct it is intended to prohibit, H.J. Inc. v. Northwestern Bell Telephone Co., 492 U.S. 229, 255-56 (1989) (Scalia, J., joined by
} 
answer came in Turkette. There the Supreme Court held with the majority of the circuit courts and found that "neither the language nor structure of RICO limits its application to legitimate "enterprises." 19 This meant that RICO would henceforth be interpreted not just as prohibiting the corruption of legitimate organizations (like labor unions, waste management companies, or Las Vegas casinos) but directly to the illegal acts of criminal organizations. ${ }^{20}$ And although this holding doesn't control all the interpretive questions that courts face, it alerts us to something approaching a truism of RICO jurisprudence: the Supreme Court is loath to interpret RICO in a way that limits its criminal reach. One can speculate as to why this might be, but "the Court's unwillingness to reject an interpretation of the statute that provides so many advantages to the government in its battle with organized crime" seems as good an explanation as any. ${ }^{21}$ With these thoughts in mind, we can now turn to some preliminary general linguistic observations.

Rehnquist, C. J., and O’Connor and Kennedy, JJ., concurring in judgment) ("No constitutional challenge to this law has been raised in the present case ... . That the highest Court in the land has been unable to derive from this statute anything more than today's meager guidance bodes ill for the day when that challenge is presented").

Anza v. Ideal Steel Supply Corp.,547 U.S. 451, 471-72 (2006) (Thomas, J., dissenting).

${ }^{19}$ Turkette, 452 U.S. at 587.

${ }^{20}$ In practice, this has made it difficult to distinguish an association-in-fact enterprise from a criminal conspiracy. See Boyle v. United States, 556 U.S. 938, 945-47 (2009) (describing what is not required for an association-in-fact enterprise).

${ }^{21}$ DAVID B. SMITH \& TERRANCE G. REED, CIVIL RICO \ 3.02[1] (2017). Justice Thomas highlights the other, civil, side of the conundrum in his Anza dissent when he notes that, among other things, civil RICO suits almost never turn on conduct that one would associate with Mafia-like behavior:

Congress plainly enacted RICO to address the problem of organized crime, and not to remedy general state-law criminal violations. See H. J. Inc. v. Northwestern Bell Telephone Co., 492 U. S. 229, 245 (1989). There is some evidence, to be sure, that the drafters knew that RICO would have the potential to sweep more broadly than organized crime and did not find that problematic. Id. at 246-248. Nevertheless, the Court has recognized that "in its private civil version, RICO is evolving into something quite different from the original conception of its enactors.” Sedima, S.P.R.L. v. Imrex Co., 473 U.S. 479, 500 (1985)

This case, like the majority of civil RICO cases, has no apparent connection to organized crime. See Sedima, 473 U. S. at 499, n.16 (quoting an ABA Task Force determination that, over the period reviewed, only $9 \%$ of civil RICO cases at the trial court 
At the outset, we must note that a "plain meaning" analysis can take us only so far. ${ }^{22}$ For as members of Congress complained at the time of its consideration, RICO "embodies poor draftsmanship," a complaint echoed in many court decisions. ${ }^{23}$ And even though Justices of the Supreme Court repeatedly insist that particular sections of RICO are "clear" or "plain," they vehemently disagree as to what that clear or plain meaning is. ${ }^{24} \mathrm{We}$ will defer for now the question of why that might be and simply register that courts often take a "plain meaning" approach to RICO provisions that are anything but plain. Nonetheless, the text is a convenient and necessary starting point. What we find in the case law are appeals to dictionary definitions, syntactic rules common to standard English, canons of construction, and the structure of the statute itself, all of which often slide into evaluative arguments about intent and purpose.

\section{Systemic Arguments}

RICO's many vagaries provide almost endless possibilities for devising systemic interpretive arguments based on policy, principles, history and the like. Here, in summary-list form, are ways with which to label some of the techniques that we will see applied in the cases that we'll soon examine in detail.

level involved "“allegations of criminal activity of a type generally associated with professional criminals"'). Given the distance the facts of this case lie from the prototypical organized criminal activity that led to RICO's enactment, it is tempting to find in the Act a limitation that will keep at least this and similar cases out of court.

Anza, 547 U.S. at 471-73 (Thomas, J., dissenting).

${ }^{22}$ For a full-blown analysis of the linguistic features of a particular RICO provision, see Gordon, Gangs and Gaggles, supra note 1, at 998-1011 (discussing "enterprise" element of RICO).

${ }^{23}$ H.R. REP. 91-1549, at 185 (1970) (dissenting views of Representative John Conyers, Jr., Abner Mikva, and William Ryan); see, e.g., H.J. Inc. v. Nw. Bell Tel. Co., 492 U.S. 229, 249 (1989) ("RICO may be a poorly drafted statute; but rewriting it is a job for Congress, if it is so inclined, and not for this Court."). ${ }^{24}$ See Sedima, S.P.R.L. v. Imrex Co., Inc., 473 U.S. 479, 494-97 (1985) (finding § 1964(c) clear, but divided on the plain meaning of the text). In Sedima, all nine Justices agreed that $\S 1964$ (c) was unambiguous, but split 5-4 as to the provision's plain meaning. See id. (holding that the plain language of $\S 1964$ (c) forecloses an "amorphous 'racketeering injury' requirement"); id. at 509-10 (Marshall, J., dissenting) (asserting that the majority's rejection of a "racketeering injury" requirement "distorts the statutory language under the guise of adopting a plain-meaning definition, and it does so without offering any indication of congressional intent that justifies a deviation from . . . the plain meaning of the statute"); see also LAWRENCE M. SOLAN, THE LANGUAGE OF JUDGES 101 (1993) (noting that "in an interesting voting paradox, the justices agreed 9-0 that the language is plain, but disagreed 5-4 about what it means"). 


\section{a. Contextual Harmonization}

"The argument from contextual harmonization looks to the way in which any statutory provision is to be found nested in a larger legal scheme, at least that of the single whole statute, often that of a set of related statutes." 25 The aim of this technique is to find the proper interpretation of a troublesome statutory provision by searching other statutory provisions that cast light back on the target. Some observers have opined that the antitrust laws and RICO serve some of the same ends: in particular, preserving a free marketplace and honest competition. So courts sometimes consider RICO claims in this light.

\section{b. Precedential Argument}

"The argument from precedent says that if a statutory provision has previously been subjected to judicial interpretation, it ought to be interpreted in conformity with the interpretation given to it by other courts." ${ }^{26}$ At this point, RICO has a substantial jurisprudential history, including many significant Supreme Court decisions.

\section{c. Analogical Argument}

Statutes do not exist in a vacuum, and so where one is faced with interpreting a statute that is significantly analogous to another, it makes good sense to interpret the one in harmony with the other. ${ }^{27}$ Section 4 of the Clayton Act and Section 1964(c) of RICO contain nearly identical language. Not surprisingly, then, courts often look to prior interpretations of the former in considering the latter.

\section{d. Conceptual Argument}

A conceptual argument, which gains its validity by appealing to the desire for coherence across a whole system, "says that if any recognized and doctrinally elaborated general legal concept is used in the formulation of a statutory provision, it ought to be interpreted so as to maintain a consistent use of the concept throughout the system as a whole." ${ }^{28}$ In some cases, a conceptual argument is a broader application of the theory behind contextual harmonization arguments. In other words, one can range further afield from a word or phrase as it is nestled in a statute or set of related statutes. Because civil RICO can be thought of as a statutory tort, courts naturally refer to

\footnotetext{
${ }^{25}$ MACCORMICK, supra note 9, at 128.

${ }^{26} \mathrm{Id}$.

${ }^{27} I d$. at 129.

${ }^{28} \mathrm{Id}$. at 130 .
} 
general tort concepts of causation when determining whether a particular claim should stand or fall for reasons of causation.

\section{e. General Principles Argument}

General principles argue that, if there are general principles of law relevant to the target statute, the statute should be interpreted in the way that is most congruent with those principles. ${ }^{29}$ An uncodified portion of RICO directs that it "shall be liberally construed to effectuate its remedial purposes." ${ }^{30}$ But there is a countervailing constitutional principle in playthe rule of lenity, which "ensures fair warning by so resolving ambiguity in a criminal statute as to apply it only to conduct clearly covered." ${ }^{31}$ As a canon of construction, the rule finds voice in the notion that criminal statutes must be strictly construed. ${ }^{32}$ Thus, if any portion of the statute were determined to be ambiguous, the rule of lenity would demand a narrow reading of the terms at issue: "RICO, since it has criminal applications as well, must, even in its civil applications, possess the degree of certainty required for criminal laws." "33

\section{f. Historical Argument}

"The argument from history takes note that a statute or group of statutes can over time come to be interpreted in accordance with a historically evolved understanding of the point and purpose of the statute, or of the group of statutes taken together as a whole." 34 One way to think about this type of argument vis-à-vis RICO is to consider the substantial precedent holding that the statute applies or does not apply in recurring scenarios. Another way is to think about the purpose of RICO and how well particular interpretations of the statute fit with that purpose. We will take up these ideas more fully later, but it is worth pausing for a moment to reflect on cases in which the Supreme Court made a policy decision to read RICO broadly so as to make more criminals subject to RICO's proscriptions and penalties. But those

\footnotetext{
${ }^{29} \mathrm{Id}$.

${ }^{30}$ Organized Crime Control Act of 1970, Pub. L. No. 91-452, § 904(a), 84 Stat. 922, 947 (1970).

${ }^{31}$ United States v. Lanier, 520 U.S. 259, 266 (1997); see also G. Robert Blakey \& Scott D. Cessar, Equitable Relief under Civil RICO: Reflections on Religious Technology Center v. Wollersheim: Will Civil RICO Be Effective Only Against White-Collar Crime?, 62 Notre DAME L. REV. 526, 546 n.74 (1987); Solan, supra note 23, at 77-81 (discussing how the Supreme Court interpreted the term "enterprise" in the context of RICO); Caroline N. Mitchell et al., Returning RICO to Racketeers: Corporations Cannot Constitute an Associated-in-Fact Enterprise Under 18 U.S.C. § 1961(4), 13 FORDHAM J. CORP. \& FIN. L. 1, at 19-20 (discussing and defining the rule of lenity).

${ }^{32}$ Lanier, 520 U.S. at 266.

${ }^{33}$ H.J. Inc. v. Nw. Bell Tel. Co., 492 U.S. 229, 255 (1989) (Scalia, J., concurring).

${ }^{34}$ MACCORMICK, supra note 342, at 130.
} 
decisions came at an associated cost: subsequent courts and even civil litigants must interpret the section in light of those holdings, which is to say in light of history. ${ }^{35}$ These consequences demand closer examination, a subject to which we now turn.

\section{Another Name}

\section{Teleological- Evaluative Arguments: Consequentialism by}

Examining the language and context of a statute are important tools in interpretation, but as MacCormick reminds us, "other values can be significant." 36 Some of these values begin to emerge from the background when we consider that statutes are not sui generis: they are the product of the purposive acts of legislators. These acts are taken "with a view to reforming the law"- to correcting what MacCormick calls a "mischief" in the existing body of law. ${ }^{37}$ Thus, an interpretation that would achieve the ends at which a statute is aimed (be it curing a defect, closing a loophole, or reforming an inequity) has much to commend it. One way of thinking about this is, as Lon Fuller once suggested, by analogy to an invention that was left as a pencil sketch at the time that its author died. ${ }^{38}$ Someone continuing that work would have to ask what the projected device was supposed to do and discern its motivating principles. According to Fuller:

[s]o it is usually with difficult problems of interpretation. If the draftsman of a statute were called into direct consultation, he would normally have to proceed in the same

\footnotetext{
${ }^{35}$ Solan suggests that courts have interpreted RICO under a "law enforcement model," meaning that courts "have been generous with prosecutors and stingy with civil plaintiffs in interpreting various provisions of the statute." Solan, supra note 3 , at 2255. This phenomenon was no doubt exacerbated by the fact that the interpretations of RICO's substantive provisions first occurred in criminal cases, where the courts were inclined to give the Government a fair amount of leeway in its fight against crime. And, as Reed and Smith note:

[t]he happenstance that civil RICO was not "discovered" by the plaintiff's bar until the 1980's has had an important influence on the development of RICO jurisprudence. Had the much deplored explosion of civil RICO litigation occurred ten years earlier, the courts would have interpreted the statute much more restrictively than they did with only criminal RICO prosecutions on their docket.
}

SMITH \& REED, supra note 20, at $93.02[1]$, n.19 (noting also that "[o]nly a handful of civil RICO cases were brought between 1970 and 1980").

${ }^{36}$ MACCORMICK, supra note 9, at 132.

${ }^{37}$ Id.; see also John F. Manning, Inside Congress's Mind, 115 COLUM. L. REV. 1911, 1924-35 (2015) (discussing the realities of the legal process versus the textualist interpretation).

${ }^{38}$ LON. L. Fuller, The Morality OF LaW 84-88 (rev. ed., Yale Univ. Press 1969). 
manner as the judge by asking such questions as the following: Does this case fall within the mischief which the statute sought to remedy? Does it fall within the "true reason of the remedy" appointed by the statute, that is, is the prescribed remedy apt for dealing with this particular manifestation of the general mischief at which the statute was aimed? ${ }^{39}$

We now consider three sets of cases in which courts have deployed the full arsenal of interpretive weapons in skirmishes set to determine RICO's territorial boundaries. I'll start with a recent Supreme Court case deciding questions concerning the extraterritorial application of RICO, proceed to cases establishing standing and causation standards, and conclude with unsettled questions relating to the availability of equitable relief.

\section{RICO INTERPRETATION IN THREE SETS}

\section{A. Does RICO have borders?}

In RJR Nabisco, Inc. v. European Community, the Supreme Court was called upon to decide two questions involving the extraterritorial reach of RICO. ${ }^{40}$ As the Court cast them: "First, do RICO's substantive prohibitions, contained in $\S 1962$, apply to conduct that occurs in foreign countries? Second, does RICO's private right of action, contained in $\S$ 1964(c), apply to injuries that are suffered in foreign countries." 41 Both these questions can be cast as problems of interpretation.

The case arrived at the Supreme Court against a complicated procedural and factual backdrop. In terms of procedure, the European Community (the EC) and six of its member states first sued RJR and several related entities for RICO violations in 2000.

The litigation spawned at least three separate actions and multiple oscillations between federal district and appellate courts. ${ }^{42}$ Of immediate concern was the district court's dismissal of the case, followed by the Second Circuit's reinstatement. ${ }^{43}$

\footnotetext{
${ }^{39} \mathrm{Id}$. at 85 .

${ }^{40}$ RJR Nabisco, Inc. v. European Cmty., 136 S. Ct. 2090, 2099 (2016).

${ }^{41}$ RJR Nabisco, 136 S. Ct. at 2098.

${ }^{42}$ See European Cmty. v. RJR Nabisco, Inc., No. 02-CV-5771, 2011 WL 843957, at *1-2 (E.D.N.Y. March 8, 2011) (cataloguing the case's procedural twists and turns).

${ }^{43}$ Compare id. at *1 (dismissing RICO claims), and European Cmty. v. RJR Nabisco, Inc., 814 F. Supp. 2d 189, 192 (E.D.N.Y. 2011) (dismissing state-law claims), with European Cmty. v. RJR Nabisco, Inc., 764 F.3d 129, 133 (2d Cir. 2014) (reversing the district court's dismissal of all claims).
} 
Reduced to the essentials, the EC alleged that RJR and organized criminal organizations participated in a global money-laundering scheme. In one thread of the scheme, Colombian and Russian drug traffickers smuggled narcotics into the EC, sold the drugs for euros, and then used these proceeds to purchase large blocks of RJR cigarettes that were sold into the EC. ${ }^{44}$ In another thread of the alleged scheme, RJR conspired with South American drug traffickers and money launderers and-in violation of international sanctions - sold cigarettes to Iraq. ${ }^{45}$ The EC also alleged that RJR's acquisition of Brown \& Williamson Tobacco Corporation was ostensibly for the purpose of expanding the pattern of illegality. ${ }^{46}$

Cast in RICO's statutory terms, the EC alleged that RJR engaged in a pattern of racketeering activity rooted in predicate acts ranging from money laundering to support of foreign terrorist organizations, mail and wire fraud, and Travel Act violations. ${ }^{47}$ RJR and its cohorts allegedly formed an association-in-fact enterprise dubbed the "RJR Money-Laundering Enterprise. $" 48$ Once assembled, these factual bits constitute an averment that RJR violated all four of RICO's criminal prohibitions: (1) using income derived from the pattern of racketeering to invest in, acquire an interest in, and operate the RJR Money-Laundering Enterprise in violation of $§ 1962$ (a); (2) acquiring and maintaining control of the enterprise through the pattern of racketeering in violation of $\$ 1962$ (b); (3) operating the enterprise through the pattern of racketeering in violation of $\$ 1962$ (c); and (4) conspiring with other schemers in violation of $\S 1962(d) .{ }^{49}$ These violations allegedly caused the EC harm, "including ... competitive harm to their state- owned cigarette businesses, lost tax revenue from black-market cigarette sales, harm to European financial institutions, currency instability, and increased law enforcement costs." 50

With respect to the first question, the Court began from the "basic premise of our legal system that, in general, 'United States law governs domestically but does not rule the world." 51 This pronouncement is rooted in a "presumption against extraterritoriality" that finds expression in a canon of statutory construction and broad policy-based holdings: "Absent clearly expressed congressional intent to the contrary, federal laws will be construed

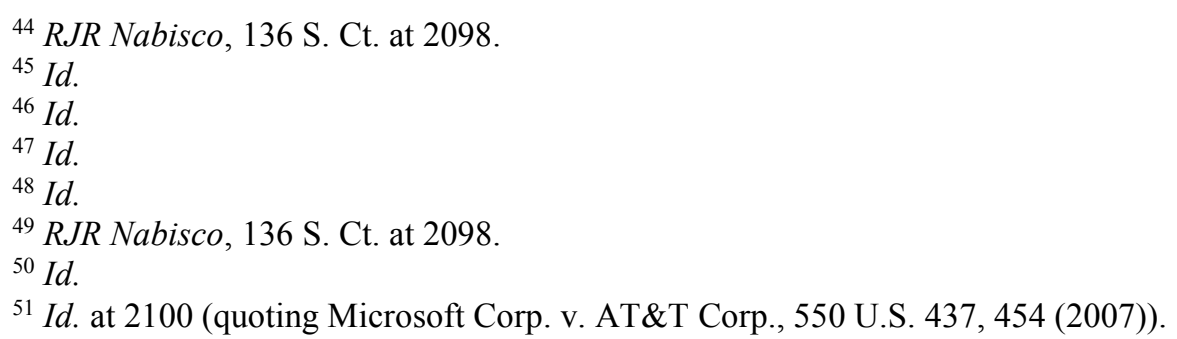


to have only domestic application." 52 So, "[w] hen a statute gives no clear indication of an extraterritorial application, it has none." 53

With this conceptual policy lens in hand, the Court moved to a more particular examination of recent precedent, first looking at a case under $\S$ 10(b) of the Securities Exchange Act and then at one under the Alien Tort Statute. ${ }^{54}$ From these two cases, which it found analogous, the Court divined an underlying "two-step framework for analyzing extraterritoriality issues." The first step is relatively straightforward: does the statute give an unequivocal, affirmative indication that it has an extraterritorial reach? ${ }^{56}$ The second step requires a more nuanced, fact-based inquiry, not just a facial statutory examination. To wit, if the statute is not by its express terms extraterritorial, then a court must determine whether the case at hand has a domestic component that pushes it into the statute's "focus." 57 To make this determination a court must winnow jurisdictionally significant facts from those that are not:

If the conduct relevant to the statute's focus occurred in the United States, then the case involves a permissible domestic application even if other conduct occurred abroad; but if the conduct relevant to the focus occurred in a foreign country, then the case involves an impermissible extraterritorial application regardless of any other conduct that occurred in U. S. territory." 58 This second step is irrelevant, however, if the statute clearly does have extraterritorial reach. In that case, the inquiry becomes largely textual: "The scope of an extraterritorial statute thus turns on the limits Congress has (or has not) imposed on the statute's foreign application, and not on the statute's 'focus.' 59

So the first question facing the Court - at least at a superficial levelwas whether the substantive provisions of $\S 1962$ apply extraterritorially. Certainly, there is no text in $\S 1962$ itself that one can point to as an unequivocal statement of extraterritorial application. But that's not the end of the inquiry because - to recall RICO's three-part structure- $\S 1962$ 's prohibitions are triggered by the existence of a pattern of racketeering activity, which is defined to include violations of numerous statutory

\footnotetext{
${ }^{52}$ Id. (citing Morrison v. Nat'l Austl. Bank Ltd., 561 U.S. 247, 255 (2010)).

${ }^{53} I d$. (internal quotations omitted).

${ }^{54}$ RJR Nabisco, 136 S. Ct. at 2100-01 (discussing Morrison, 561 U.S. 247, and

Kiobel v. Royal Dutch Petroleum Co., 133 S. Ct. 1659 (2013)).

${ }^{55} \mathrm{Id}$. at 2101.

${ }^{56} \mathrm{Id}$.

${ }^{57} \mathrm{Id}$.

${ }^{58} I d$.

${ }^{59}$ RJR Nabisco, 136 S. Ct. at 2101.
} 
predicates. The Court thus pivoted to an examination of these other statutes and easily found that many of them do expressly apply with extraterritorial force. ${ }^{60}$ For example:

- 18 U. S. C. $\$ 1957(d)(2)$ prohibits transactions in criminally derived property, including when "the defendant is a United States person" and even if the offenses "tak[e] place outside the United States."

- $\quad \S 351(\mathrm{i})$ prohibits the assassination of Government officials and "There is extraterritorial jurisdiction over the conduct prohibited by this section"; 62

- $\S 1203(\mathrm{~b})$ prohibits against hostage taking in a range of circumstances even if the critical acts "occurred outside the United States"; 63 and

- $\$ 2332(a)$ prohibits "kill[ing] a national of the United States, while such national is outside the United States," a prohibition that can only to conduct occurring outside the United States. ${ }^{64}$

From this, the Court concluded that "Congress's incorporation of these (and other) extraterritorial predicates into RICO gives a clear, affirmative indication that $\S 1962$ applies to foreign racketeering activity." $" 65$ But this does not mean that $\S 1962$ always applies extraterritorially; rather, it only has that scope to the extent "that the predicates alleged in a particular case themselves apply extraterritorially." activity may include or consist of offenses committed abroad in violation of a predicate statute for which the presumption against extraterritoriality has been overcome." ${ }^{\prime 67}$

This holding comes with an important limitation, though. For purposes of assessing extraterritorial liability under $\S 1962$, only those predicate acts with extraterritorial effect will "count." This is so for two reasons. First, as a general matter the presumption against extraterritoriality

\footnotetext{
${ }^{60} \mathrm{Id}$.

${ }^{61} I d$. (internal quotations omitted).

${ }^{62}$ Id. (internal quotations omitted); see also 18 U.S.C. $§ 1751(\mathrm{k})$ (using the same language as $\S 351(\mathrm{i})$ ).

${ }^{63}$ RJR Nabisco, $136 \mathrm{~S}$. Ct. at 2101-02 (internal quotations omitted).

${ }^{64} \mathrm{Id}$. at 2102 (internal quotations omitted).

${ }^{65} \mathrm{Id}$.

${ }^{66} \mathrm{Id}$.

${ }^{67} \mathrm{Id}$.
} 
limits the scope of a statement of extraterritoriality to its terms. ${ }^{68}$ Second, and more specifically, "RICO defines as racketeering activity only acts that are 'indictable' ... . If a particular statute does not apply extraterritorially, then conduct committed abroad is not 'indictable' under that statute and so cannot qualify as a predicate under RICO's plain terms." 69

At the end of this analysis, we may safely conclude that RICO covers some foreign racketeering activity - viz., "a pattern of racketeering that includes predicate offenses committed abroad, provided that each of those offenses violates a predicate statute that is itself extraterritorial." 70 If properly pled and proven, this fact will be outcome determinative of the extraterritoriality question under $\S$ 1962(b) and $\S$ 1962(c) because both prohibit the use of a pattern of racketeering in achieving certain ends. ${ }^{71}$ $\S 1962$ (b) (barring use of pattern of racketeering activity both to acquire or maintain control of an enterprise and to conduct the affairs of an enterprise).$^{72}$ With respect to the latter, the Court left the matter open to later decision; with respect to the former, the Court concluded that because $\S 1962$ (a) targets the use of income derived from a pattern of racketeering rather than the use of the pattern itself, § 1962(a) might well extend only to domestic uses of the income. ${ }^{73}$ But because the issue made no difference in the case at hand, the Court left that issue, too, undecided. ${ }^{74}$

To this point, the Court established only that a substantive, criminal violation of RICO can, in proper circumstances, be predicated on foreign conduct. But what about a civil claim? To answer that question, the Court undertook an analysis of $\S 1964$ (c), which, to recall our earlier discussion, permits "any person injured in his business or property by reason of a violation of section 1962" to sue for treble damages, costs, and attorney's fees. ${ }^{75}$ At the outset of the analysis, the Court determined that it must "separately apply the presumption against extraterritoriality to RICO's cause of action despite our conclusion that the presumption has been overcome with

\footnotetext{
${ }^{68}$ RJR Nabisco, 136 S. Ct. at 2102.

${ }^{69} I d$.

${ }^{70} \mathrm{Id}$. at 2103.

${ }^{71} 18$ U.S.C. $\S 1962$ (b) (2016) (barring use of pattern of racketeering activity both to acquire or maintain control of an enterprise and to conduct the affairs of an enterprise).

${ }^{72}$ RJR Nabisco, 136 S. Ct. at 2103.

${ }^{73} \mathrm{Id}$.

${ }^{74} \mathrm{Id}$. The Court went on to consider another technical RICO-specific issue: viz., whether a RICO claim must be predicated on the existence of a domestic "enterprise." The Court held that it need not be, although "a RICO enterprise must engage in, or affect in some significant way, commerce directly involving the United States - e.g., commerce between the United States and a foreign country. Enterprises whose activities lack that anchor to U. S. commerce cannot sustain a RICO violation." Id. at 2105.

${ }^{75} \S 1964(c)$.
} 
respect to RICO's substantive prohibitions."76 The reason for this conclusion resides in notions of international comity: "providing a private civil remedy for foreign conduct creates a potential for international friction beyond that presented by merely applying U. S. substantive law to that foreign conduct."77

As a specific example, the Court considered antitrust law, which it had previously noted that private treble-damages actions generated considerable controversy abroad, even when the affected foreign states agreed with the U.S. on substantive points of law (e.g., price fixing should be condemned) ${ }^{78}$ In an ironic twist, the Court noted that two of the claimants (including Germany and France) had argued in other cases that "to apply [U. $\mathrm{S}$.] remedies would unjustifiably permit their citizens to bypass their own less generous remedial schemes, thereby upsetting a balance of competing considerations that their own domestic antitrust laws embody."79 In an attempt to slip this knot, the claimant countries urged the Court to draw a distinction between suits brought by foreign citizens and those brought by foreign sovereigns. ${ }^{80}$ The court "refuse[d] to adopt this double standard." 81

The Court then moved to a textual examination and-finding no explicit reference to extraterritoriality - spent the remainder of its effort knocking down appeals to precedent and arguments by analogy. First, the Court considered the statement in Sedima that "compensable injury" identified in $\S 1964(c)$ "necessarily is the harm caused by predicate acts sufficiently related to constitute a pattern." 82 The EU argued that this equivalence put an end to the matter; the Court said it begged the question because "the presumption against extraterritoriality must be applied separately to both RICO's substantive prohibitions and its private right of action." ${ }^{83}$ Second, the Court considered the EU's argument that a long history supports the notion that American courts are open to plaintiffs injured abroad. The Court found that this rule, too, begged the question because it does nothing more than allow plaintiffs to sue in U.S. courts and have foreign law provide the rule of decision. ${ }^{84}$

Finally, the Court considered the EU's argument that $\S 1964(c)$ should be interpreted and applied in pari materia to its direct ancestor, $\S 4$ of the Clayton Act. In other words, so the reasoning goes, because the Court had

\footnotetext{
${ }^{76}$ RJR Nabisco, 136 S. Ct. at 2106.

${ }^{77} I d$.

${ }^{78} \mathrm{Id}$.

${ }^{79} \mathrm{Id}$. at $2106-07$.

${ }^{80} \mathrm{Id}$. at 2108

${ }^{81}$ RJR Nabisco, 136 S. Ct. at 2108.

${ }^{82} \mathrm{Id}$. (internal quotations omitted).

${ }^{83} \mathrm{Id}$.

${ }^{84} \mathrm{Id}$. at 2109.
} 
held that $\S 4$ allows recovery for injuries suffered abroad, consistency demands that $\S 1964$ (c) be read to provide the same private right of action. ${ }^{85}$ But the Court disagreed, finding that - although the Clayton Act could sometimes offer "guidance in construing $§ 1964(c)$ " - it had "not treated the two statutes as interchangeable." ${ }^{\circ 6}$ As an example, the Court pointed to Sedima, in which it rejected a "racketeering injury" pleading requirement that some lower courts had adopted by "[a]nalog[y]" to the "antitrust injury" requirement of the Clayton Act. ${ }^{87}$

The Court was also at some pains to distinguish Pfizer, in which the Court held that the Clayton Act allows recovery for foreign injuries. In particular, the Court noted that Pfizer turned on a finding that the Clayton Act's definition of a "person" entitled to sue "explicitly includes 'corporations and associations existing under or authorized by ... the laws of any foreign country." 88 Because RICO lacks this language, the analogy is considerably weakened. And to the extent that Pfizer cited other factors that could cast light on $\S 1964(\mathrm{c})$, "they were not sufficient in themselves to show that the provision has extraterritorial effect." ${ }^{\prime 9}$ Finally, the Court rejected, as an already discredited approach, the policy-based reasoning that a finding of no extraterritoriality might allow a wrongdoer to escape "full liability for his illegal actions." 90

In a parting shot, the Court invoked the Foreign Trade Antitrust Improvements Act of 1982 which - in the Court's reading - sharply reduced the ability of private plaintiffs to sue for conduct that "causes only foreign injury." "91 The Court conceded that this enactment does not limit $\S$ 1964(c)'s scope by its own force, but "it does counsel against importing into RICO those Clayton Act principles that are at odds with our current extraterritoriality doctrine." 92

In a concurring and dissenting opinion, Justice Ginsberg agreed that "when the predicate crimes underlying invocation of $\S 1962$ thrust extraterritorially, so too does $\S 1962 .{ }^{.93}$ But she sharply disagreed "that the private right of action authorized by $\S 1964$ (c) requires a domestic injury to a person's business or property and does not allow recovery for foreign

${ }^{85} \mathrm{Id}$.

${ }^{86}$ RJR Nabisco, 136 S. Ct at 2109.

${ }^{87} \mathrm{Id}$.

${ }^{88} \mathrm{Id}$.

${ }^{89} \mathrm{Id}$. at 2110.

${ }^{90} \mathrm{Id}$.

${ }^{91}$ RJR Nabisco, 136 S. Ct at 2110 (quoting F. Hoffmann-La Roche Ltd. v.

Empagran S.A., 542 U.S. 155, 158 (2004)).

${ }^{92} \mathrm{Id}$. at $2110-11$.

${ }^{93} I d$. at 2112 (Ginsberg, J. concurring). 
injuries." 94 The reason is textual: "One cannot extract such a limitation from the text of $\S 1964$ (c), which affords a right of action to '[a]ny person injured in his business or property by reason of a violation of section 1962." "95 Read in this light, the question presented thus becomes, how can $\S 1964(\mathrm{c})$ exclude claims that all agree are covered by $\S 1962$ "when, by its express terms, $\S$ 1964 (c) is triggered by 'a violation of section 1962'?"96 To answer this question, Justice Ginsberg pursued three lines of argument.

First, she appealed to precedent that linked - not separated"prohibited activities and authorized remedies." 97 Sedima, in particular, held that "[i]f the defendant engages in a pattern of racketeering activity in a manner forbidden by [ $\S 1962]$, and the racketeering activities injure the plaintiff in his business or property, the plaintiff has a claim under $\S$ 1964(c)."98 Next, she noted that "the Court has long understood," that "[i]ncorporating one statute ... into another ... serves to bring into the latter all that is fairly covered by the reference." 99 Thus, because a $§ 1964$ (c) right of action may be maintained by

[a]ny person injured in his business or property by reason of a violation of section 1962, . . . RICO's private right of action, it cannot be gainsaid, expressly incorporates $\S 1962$, whose extraterritoriality, the Court recognizes, is coextensive with the underlying predicate offenses charged. $^{100}$

With respect to the majority's objections rooted in notions of extrasystemic comity, Justice Ginsberg made two general points. First,

Invoking the presumption against extraterritoriality as a bar to any private suit for injuries to business or property abroad, this case suggests, might spark, rather than quell, international strife. Making such litigation available to domestic but not foreign plaintiffs is hardly solicitous of international comity or respectful of foreign interests. ${ }^{101}$

Second, RICO's definitional provisions implicitly exclude "[e]ntirely foreign activity" because a criminal act counts as a RICO

\footnotetext{
${ }^{94} \mathrm{Id}$.

${ }^{95} \mathrm{Id}$. at $2112-13$.

${ }^{96}$ RJR Nabisco, $136 \mathrm{~S}$. Ct at 2113.

${ }^{97} \mathrm{Id}$.

${ }^{98}$ Sedima, S.P.R.L. v. Imrex Co., Inc., 473 U.S. 479, 495 (1985).

${ }^{99}$ RJR Nabisco, 136 S. Ct. at 2113 (alterations in original) (Ginsberg, J., concurring) (quoting Pan. R. Co. v. Johnson, 264 U.S. 375, 392 (1924)).

${ }^{100} I d$.

${ }^{101} I d$.
} 
predicate only when it is "chargeable under state law" or indictable under specific federal statutes. ${ }^{102}$ And, in any event, ample procedural mechanisms are available to weed out cases with an insufficient nexus to the U.S., including the doctrine of forum non conveniens and the due process shackles placed on the exercise of personal jurisdiction over foreign corporations. ${ }^{103}$

Finally, Justice Ginsberg observed that her analysis comports with both statutory history and broad notions of normative coherence: "As this Court has repeatedly observed, Congress modeled $\S 1964$ (c) on $\S 4$ of the Clayton Act, 15 U. S. C. $\S 15$, the private civil-action provision of the federal antitrust laws, which employs nearly identical language . . ."104 And given that the Court had repeatedly held that Clayton Act $\S 4$ provides a remedy for foreign injuries, ${ }^{105}$ "[t] he similarity of language in [the two statutes] is, of course, a strong indication that [they] should be interpreted pari passu," 106 a harmonizing course that the Court had pursued in other cases. ${ }^{107}$ Whether and to what extent this "similarity of language" should control the flow of interpretation remains an open question and is one to which we will now turn with greater probity.

\section{B. Who has standing under $\S 1964$ (c) of RICO and $\S 4$ of the Clayton Act?}

Although, as we've seen, the language of $\S 1964$ (c) of RICO is derived from $\S 4$ of the Clayton Act, each exists within a different interpretive context. ${ }^{108}$ By the same token, the shared language, which is open textured,

\footnotetext{
${ }^{102}$ Id. at 1115 (quoting European Cmty. v. RJR Nabisco, Inc., 783 F.3d 123, 143

(2d Cir. 2015) (Lynch, J., dissenting from denial of rehearing en banc)).

103 Id.

${ }^{104}$ Id. at 2113-14 (citing Klehr v. A.O. Smith Corp., 521 U.S. 179, 189-190

(1997); Holmes v. Sec. Inv'r Prot. Corp., 503 U. S. 258, 267-68 (1992); Sedima,
} 473 U. S. at 485,489$)$ ).

${ }^{105} I d$. at 2114 (citing Pfizer Inc. v. Gov’t of India, 434 U. S. 308, 313-314 (1978);

Cont'l Ore Co. v. Union Carbide \& Carbon Corp., 370 U. S. 690, 707-08 (1962)).

${ }^{106} \mathrm{Id}$. (alterations in original) (internal quotations omitted) (quoting Northcross $\mathrm{v}$.

Bd. of Educ., 412 U.S. 427, 428 (1973) (per curiam)).

${ }^{107}$ Id. (citing Klehr, 521 U. S. at 188-89; Holmes, 503 U.S. at 268; Agency

Holding Corp. v. Malley-Duff \& Assocs., Inc., 483 U.S. 143, 155-156 (1987)).

${ }^{108}$ I'll touch again on this subject later, but federal antitrust law has undergone what we might think of as "purposive reassignment" in the hands of the courts. Broadly stated, "Congress's objectives included not only the economic goal of low prices and high quality brought about through competition, but also social and political ends." David F. Shores, Antitrust Decisions and Legislative Intent, 66 Mo. L. REV. 725, 747 (2001). We see this view enshrined in the earliest cases, which found all restraints - reasonable or not-illegal. See, e.g., United States v. TransMo. Freight Ass'n, 166 U.S. 290 (1897). This view quickly eroded in favor of condemning only "unreasonable" restraints, and by the time we get to the late the 1970s, the Supreme Court migrated to the view that antitrust claims must be 
presents interpretive challenges and opportunities for mischief. And since $\S$ 4 already had a long institutional interpretive history at the time of $\S$ 1964(c)'s adoption, additional questions arise as to whether the two sections should be interpreted and applied in parallel (and, if so, how far down the line).

The operative language of the two sections is deceptively simple: "any person injured in his business or property by reason of" a substantive antitrust or RICO violation may seek treble damages. ${ }^{109}$ But this simplicity "belies the complexity of the many questions it has raised." 110 These questions are, in many respects, merely a function of the breadth of the language. For example, read literally, any person, no matter how remotely or unforeseeably, injured by forbidden conduct can state a claim under either statute. So courts have concluded that the right to civil recovery cannot be that free ranging and have devised many ways to corral such claims. ${ }^{111}$ It is well beyond our present scope to trace the development and to examine the finer points of these limiting doctrines, but a sketch of the major contours of the doctrines will sufficiently illustrate our larger theoretical point. We'll start with antitrust law, then move to consider how, why, and in what respects RICO is treated differently.

In an integrated market economy like ours, an antitrust violation is bound to have ripple effects that travel far beyond the immediate actors; some decision must be made as to whether every injured person-no matter how remotely-will be permitted to sue. ${ }^{112}$ Courts have answered this question in the negative, but their rationales for doing so are varied and-as we will see- turn on notions of what evils the antitrust laws are designed redress.

\footnotetext{
grounded in "demonstrable economic effect." Cont'1 T.V., Inc. v. GTE Sylvania Inc., 433 U.S. 36, 54 (1977).

10918 U.S.C. $\S 1964(\mathrm{c})(2012)$.

${ }^{110}$ Herbert HovenKemp, Federl Antitrust Policy $\S 16.1,804$ (5th ed. 2011).

${ }^{111} I d$. ("By its language, $\S 4$ appears to give a cause of action to every person who is injured by a cartel or overcharging monopolist. The courts have concluded that the statute cannot be as broad as it purports to be, however, and they have devised ways to limit its scope."); see also, e.g., Ill. Brick Co. v. Illinois, 431 U.S. 720, 737-41 (1977) (holding that, in the context of illegal overcharging, only the overcharged direct purchaser - and not others down the line - constitute a person "injured in his business or property").

112 HovenKEMP, supra note 108 , at $\S 16.2,806$. The Clayton Act's provisions essentially encourage litigation by people for whom the amount of recovery discounted by the probability of success would otherwise be marginal. For example, a common law breach of contract action providing single damages and no attorney's fees might not be worth the risk; but if the action could be turned into an antitrust violation, the outcome may look much more appealing. Plaintiffs are continually tempted to turn every claimed business tort or contract breach into an antitrust violation as well.
} 
The threshold limiting devices are packaged under the rubric of "antitrust standing," which requires a court-in addition to finding constitutional standing under Article III-to answer three separate questions: "[(1)] have plaintiffs alleged injury in fact; [(2)] have they alleged antitrust injury[;] and [(3)] are they efficient enforcers of the antitrust laws?"113 Because having no injury in fact at all would usually cause a failure of Article III standing, the antitrust standing inquiry typically focuses on the latter two questions.

As a judicial concept, "antitrust injury" traces to the Supreme Court's pronouncements in Brunswick Corp. v. Pueblo Bowl-O-Mat, Inc. ${ }^{114}$ That case arose after the defendant, a major manufacturer and distributor (sometimes on credit) of bowling equipment and a significant operator of bowling alleys, acquired several failing alleys that had (1) defaulted on their repayment obligations, and (2) competed with the plaintiff. ${ }^{115}$ Plaintiffs' antitrust theory was that these alleys would have gone out of business but-for defendant's acquisition of them, that the acquisition violated $\S 7$ of the Clayton Act, and that had the unlawfully acquired alleys gone out of business, plaintiffs' business would have grown. ${ }^{116}$ So, in essence, the Court was called upon to evaluate a claim of injury flowing from too much competition. $^{\mathbf{1 1 7}}$

This claim struck the Court as contradictory to the purpose of the antitrust laws, which "were enacted for 'the protection of competition, not competitors." "118 The plaintiffs might have been injured, but "it was not 'by reason of anything forbidden in the antitrust laws': while [their] loss occurred 'by reason of' the unlawful acquisitions, it did not occur 'by reason of' that which made the acquisitions unlawful." "119 This means that a plaintiffs cannot recover merely upon a showing of an injury causally linked to a substantive antitrust violation: "Plaintiffs must prove antitrust injury, which is to say injury of the type the antitrust laws were intended to prevent and that flows from that which makes defendants' acts unlawful. The injury should reflect the anticompetitive effect either of the violation or of anticompetitive acts

\footnotetext{
${ }^{113}$ In Re Zinc Antitrust Litig., 155 F. Supp. 3d 337, 357 (S.D.N.Y 2016); see also Gatt Commc'ns, Inc. v. PMC Assocs., L.L.C., 711 F.3d 68, 75 (2d Cir. 2013) ("The right to pursue private actions for treble damages under $\S 4$ has ... developed limiting contours over the thirty years since Associated General Contractors was handed down. Those contours are embodied in the concept of 'antitrust standing."').

${ }^{114}$ Brunswick Corp v. Pueblo Bowl-O-Mat, Inc., 429 U.S. 477 (1977).

${ }^{115}$ Id. at $479-80$.

${ }^{116} \mathrm{Id}$. at $480-482$.

${ }^{117} I d$. at 489 ("At base, respondents complain that by acquiring the failing centers petitioner preserved competition, thereby depriving respondents of the benefits of increased concentration.").

${ }^{118} I d$. at 488 (quoting Brown Shoe Co. v. United States, 370 U.S. 294, 320 (1962)). ${ }^{119} I d$.
} 
made possible by the violation." $" 120$ What this represents is an ascription of what the antitrust laws are supposed to do (and not do): "[T] objective of antitrust policy is to maximize consumer welfare by encouraging firms to behave competitively." 121 This determination of the objective of the antitrust laws was not inevitable: one could easily imagine that the laws were enacted to provide "justice, fairness, or the preservation of opportunities for small businesses." 122

\section{Who is an Efficient Enforcer?}

The other difficult question bearing on antitrust standing is whether a plaintiff is an "efficient enforcer" of the antitrust laws. ${ }^{123}$ Courts have articulated various formulations of the factors to consider in making an efficient-enforcer determination, but the Second Circuit's list is fairly representative: "(1) the 'directness or indirectness of the asserted injury,' which requires evaluation of the 'chain of causation' linking [plaintiffs'] asserted injury and the [defendants'] alleged [antitrust violation]; (2) the 'existence of more direct victims of the alleged [violation]'; (3) the extent to which [plaintiffs'] damages claim is 'highly speculative'; and (4) the importance of avoiding 'either the risk of duplicate recoveries on the one hand, or the danger of complex apportionment of damages on the other.",124 "The efficient enforcer factors reflect a concern about whether the putative plaintiff is a proper party to perform the office of a private attorney general and thereby vindicate the public interest in antitrust enforcement." 125

\footnotetext{
${ }^{120} I d$. at 489.

${ }^{121}$ Kirtsaeng v. John Wiley \& Sons, Inc., 133 S. Ct. 1351, 1363 (2013) (alteration in original) (quoting AREEDA \& HOVENKAMP, ANTITRUST LAW 100 p. 4 (3d ed. 2006); see also NCAA v. Bd. of Regents, 468 U.S. 85, 107 (1984) (“Congress designed the Sherman Act as a consumer welfare prescription."). 122 HovenKAMP, supra note 108, at $\S 16.2,806$; but see Cont'l T.V., Inc. v. GTE Sylvania Inc., 433 U.S. 36, 59 (1977) (ruling in favor of the manufacturer-rather than the smaller retail store - in holding that the a court should apply the rule of reason to vertical non-price restraints); Leegin Creative Leather Prods., Inc. v. PSKS, Inc, 551 U.S. 877, 908 (2007) (acknowledging that "a basic antitrust objective" is "providing consumers with a free choice about" "lower prices [rather than] more service," but ruling in favor of the manufacturer-rather than the smaller retail store-in holding that a court should apply the rule of reason to vertical price restraints).

${ }^{123}$ See Daniel v. Am. Bd. of Emergency Med., 428 F.3d 408, 443 (2d Cir. 2005)

("“A showing of antitrust injury is necessary, but not always sufficient,' to establish standing.") (quoting Cargill, Inc. v. Monfort of

Colo., Inc., 479 U.S. 104, 110 n.5 (1986)).

${ }^{124}$ Gelboim v. Bank of Am. Corp., 823 F. 3d 759, 778 (2d Cir. 2016) (quoting Associated Gen. Contractors v. Cal. State Council of Carpenters, 459 U.S. 519, 540-45 (1983)).

${ }^{125} \mathrm{Id}$. at 780 (internal quotations omitted).
} 
This last statement gets to the nub of the issue: courts have searched for ways to permit private antitrust enforcement without proliferating an unmanageable volume of cases. The "factors" and "tests" (like the one I just recited) are designed to pare back the number of potential plaintiffs. From this exercise, we can discern a set of institutional preferences. First, direct injuries - as in all tort law - are preferred over "indirect" injuries. Second, plaintiffs must fall within the class of a statute's targeted beneficiaries as determined through ordinary statutory interpretation-direct customers and competitors of the violator are typically favored. ${ }^{126}$ Running in the other direction, we find a set of dislikes-indirect purchasers, nonpurchasers, employees, shareholders, creditors, and more.

Taken in tandem, the antitrust-injury and efficient-enforcer rules sharply reduce the number of cognizable private antitrust claims across two dimensions. Antitrust injury cuts out plaintiffs with injuries found to be outside the purview of the antitrust laws; efficient enforcer cuts out plaintiffs with injuries that need not be addressed via private- party litigation. ${ }^{127}$ Now why antitrust jurisprudence evolved in this way is well beyond our present scope, but it's worth noting that over time courts migrated from condemning conduct that seemed unfair and harmed small businesses to condemning only conduct that causes demonstrable deleterious effects. ${ }^{128}$

\section{Problems of Causation for RICO Standing}

As a very broadly stated proposition, courts look to antitrust precedent when formulating approaches to RICO standing. ${ }^{129}$ But this comes

\footnotetext{
${ }^{126}$ Ill. Brick Co. v. Illinois, 431 U.S. 720, 737-41 (holding that, in the context of illegal overcharging, only the overcharged direct purchaser-and not others down the line-constitute a person "injured in his business or property").

${ }^{127}$ HoveNKAMP, supra note 108, at $\S 16.3(\mathrm{~b}), 812$ ("The purpose of the antitrust injury requirement ... [is to ensure] that the harm claimed by the plaintiff corresponds to the rationale for finding a violation of the antitrust laws in the first place.").

${ }^{128}$ Cont'1 T.V., Inc. v. GTE Sylvania Inc., 433 U.S. 36, 59 (1977) (holding that the rule of reason, rather than a per se rule, should be applied to the defendant's vertical territorial restraints in its franchise agreements); see also Leegin Creative Leather Prods., Inc. v. PSKS, Inc, 551 U.S. 877, 908 (2007) (holding that "[v]ertical price restraints are to be judged according to the rule of reason" rather than by a per se rule, thereby overruling Dr. Miles Med. Co. v. John D. Park \& Sons Co., 220 U.S. 373 (1911)); see also Shores, supra note 106, at 728 ("[R]ecent decisions leave no doubt that the Court has revised its view concerning the purpose or goals of the antitrust laws.").

${ }^{129}$ Jackson v. Sedgwick Claims Mgmt. Servs., Inc., 731 F. 3d 556 (6th Cir. 2013) ("With respect to $\S 1964(c)$, [its] limits have often been derived from the similarities between RICO and the antitrust laws ... Courts have therefore looked to $\S 4$ of the Clayton Act; its predecessor, $\S 7$ of the Sherman Act; and cases
} 
with a significant caveat - the Supreme Court fairly quickly squelched the efforts of lower courts to develop-by- analogy notions of "racketeering injury" and "competitive injury." 130 In Sedima, the Court found nothing in the statute suggesting that relief would be available only for a "racketeering injury," a concept that the Court found vague and "unhelpfully tautological."131 But with respect to the efficient enforcer doctrine, with its emphasis on directness of injury and proximate causation, ${ }^{132}$ courts have hewed much closer to the antitrust precedents. ${ }^{133}$ For example, under the Ninth Circuit rubric, courts should consider:

(1) whether there are more direct victims of the alleged wrongful conduct who can be counted on to vindicate the law as private attorneys general; (2) whether it will be difficult to ascertain the amount of the plaintiff's damages

construing these statutes in order to identify limits to the civil remedy afforded by $\S$ 1964(c).”).

${ }^{130}$ See Sedima, S.P.R.L. v. Imrex Co., Inc., 473 U.S. 479, 499-500 (1985) (“In borrowing its 'racketeering injury' requirement from antitrust standing principles, the court below created exactly the problems Congress sought to avoid."); see also Cohen v. Trump, 200 F. Supp. 3d 1063, 1069 (S.D. Cal. 2016) ("[T]he Supreme Court rejected the Second Circuit's attempt to read RICO to impose liability only against defendants who had been criminally convicted, and only for what the court called 'racketeering injury."'). The Sedima Court also rejected a reading of 1964(c) under which a claim could only be predicated on a prior conviction. Sedima, 473 U.S. at 488 ("[A] prior conviction-requirement cannot be found in the definition of 'racketeering activity.' Nor can it be found in $\S 1962$, which sets out the statute's substantive provisions.").

${ }^{131}$ Sedima, 473 U.S. at 494.

${ }^{132}$ As a matter of diction, there is some surface confusion in the case law as to whether the issue should be labeled as part of a "standing" or "proximate causation" inquiry. The Sixth Circuit explains: "the two concepts overlap and that is particularly true in the context of civil RICO claims. As a general matter, they overlap because a plaintiff who lacks standing to vindicate a derivative injury also will be unable to show proximate cause." Trollinger v. Tyson Foods, Inc., 370 F.3d 602, 613 (6th Cir. 2004). For our purposes, this labeling makes no difference because we're interested in the function of limiting doctrines, not what they're called. In practice, though, categorization can make a significant litigation difference, given that standing is a threshold Rule 12 issue and causation can often be deferred to Rule 56 practice (or even trial). See id. at 615 ("From a procedural standpoint, a RICO case with a derivative-injury problem is better suited to dismissal on the pleadings than a RICO case with a traditional proximate-cause problem (e.g., a weak or insubstantial causal link, a lack of foreseeability, or a speculative or illogical theory of damages.)").

${ }^{133}$ See Holmes v. Sec. Inv'r Prot. Corp., 503 U. S. 258, 279 (1992) ("Today, the Court sensibly holds that the statutory words 'by reason of' operate, as they do in the antitrust laws, to confine RICO's civil remedies to those whom the defendant has truly injured in some meaningful sense."); see also Hemi Group, LLC v. City of New York, 559 U.S. 1, 11 (2010) (citing Associated Gen. Contractors, Inc. v. Cali. State Council of Carpenters, 459 U.S. 519, 541 n.46 (2010)). 
attributable to defendant's wrongful conduct; and (3) whether the courts will have to adopt complicated rules apportioning damages to obviate the risk of multiple recoveries. ${ }^{134}$

The Supreme Court tends to frame these inquiries in terms of causation, and in this respect, there's a clear line connecting the antitrust and RICO approaches. For example, in a seminal causation case, Holmes $v$. Securities Investor Protection Corp., ${ }^{135}$ the Court was called upon to decide whether a plaintiff has standing to sue for a RICO violation that proximately injures a third party and also derivatively injures the plaintiff. ${ }^{136}$ This presented a familiar and analogous question of tort-law causation: is but-for causation sufficient to confer standing under $\S 1964(c) ?^{137}$

The matter could not be resolved at a textual level because the "language can . . . be read to mean that a plaintiff is injured 'by reason of' a RICO violation, and therefore may recover, simply on showing that the defendant violated $\S 1962$, the plaintiff was injured, and the defendant's violation was a 'but for' cause of plaintiff's injury." "138 The Court rejected this reading for reasons of analogy and precedent. Section 1964(c) is modeled on $\S 4$ of the Clayton Act, ${ }^{139}$ which had been held to "incorporate common-law

\footnotetext{
${ }^{134}$ Newcal Indus., Inc. v. Ikon Office Sol., 513 F.3d 1038, 1055 (9th Cir. 2008).

${ }^{135}$ Holmes v. Securities Investor Protection Corp., 503 U.S. 258, 272 (1992).

${ }^{136}$ See id. at $265 \mathrm{n} .7$. The petition phrased the question as follows:

Whether a party which was neither a purchaser nor a seller of securities, and for that reason lacked standing to sue under Section 10(b) of the Securities Exchange Act of 1934 and Rule $10 \mathrm{~b}-5$ there under, is free of that limitation on standing when presenting essentially the same claims under the Racketeer Influenced and Corrupt Organizations Act.

Id. (citation omitted).

${ }^{137}$ See id. at 266-67, 266 n.12.

${ }^{138}$ Id. at $265-266$.

${ }^{139} I d$. ("This construction is hardly compelled, however, and the very unlikelihood that Congress meant to allow all factually injured plaintiffs to recover persuades us that RICO should not get such an expansive reading."); see also Clayton Act of 1914 , ch. $323, \S 4$, 38 Stat. 731 (codified as amended at 15 U.S.C. $\S 15$ (1982)). See Holmes, 503 U.S. at 267, which states:

We have repeatedly observed that Congress modeled $\S 1964$ (c) on the civil-action provision of the federal antitrust laws [and] $\S$ 4 of the Clayton Act, which reads in relevant part that 'any person who shall be injured in his business or property by reason of anything forbidden in the antitrust laws may sue therefor ... and shall recover threefold the damages by him sustained, and the cost of suit, including a reasonable attorney's fee.
} 
principles of proximate causation." "140 The Court saw no reason that this holding should not extend to $\S 1964(\mathrm{c})$ :

We may fairly credit the 91 st Congress, which enacted RICO, with knowing the interpretation federal courts had given the words earlier Congresses had used first in $\S 7$ of the Sherman Act and later in the Clayton Act's $\S$ 4. It used the same words, and we can only assume it intended them to have the same meaning that courts had already given them. ${ }^{141}$ required." 142

As a matter of systemic coherence, then, "[p]roximate cause is thus

The Court could not, of course, articulate a one-size-fits-all test for determining proximate cause, so open questions remained (and still remain). ${ }^{143}$ But there could be no doubt that Clayton Act precedent would thereafter be a relevant point of departure. The Court recently reconfirmed this in Anza v. Ideal Steel Supply Corp., where it specifically invoked Holmes's reliance on $\S 4$ :

Proper interpretation of $\$ 1964(\mathrm{c})$ required consideration of the statutory history, which revealed that "Congress modeled $\S 1964(\mathrm{c})$ on the civil-action provision of the federal antitrust laws, $\S 4$ of the Clayton Act." In Associated Gen. Contractors of Cal., Inc. v. Carpenters, 459 U. S. 519 (1983), the Court held that "a plaintiff's right to sue under $\S$ 4 required a showing that the defendant's violation not only was a 'but for' cause of his injury, but was the proximate

\footnotetext{
${ }^{140}$ See Holmes, 503 U.S. at 267-68 (stating that Congress's use of $\S 7$ language in $\S 4$ has been interpreted by the Court to indicate the same congressional intent, and therefore the Court has previously held that $\S 4$ required a showing of proximate causation).

${ }^{141} I d$. at 268 (citations omitted).

${ }^{142} I d$.

${ }^{143} I d$. (referring the lower courts to "the judicial tools used to limit a person's responsibility for the consequences of that person's own acts"). The Court also observed that "[a]t bottom, the notion of proximate cause reflects "ideas of what justice demands, or of what is administratively possible and convenient." Id. (quoting W. Page Keeton et al., Prooser \& KeEton on the LaW of Torts $\S$ 41, at 264 (5th ed. 1984)). The court went on to say, "accordingly, among the many shapes this concept took at common law, was a demand for some direct relation between the injury asserted and the injurious conduct alleged." Id. (citations omitted).
} 
cause as well." This reasoning, the Court noted in Holmes, "applies just as readily to $\S 1964(c) . " 144$

But we must remember that this analogy and related statutory history is just a starting point. So although it is a commonplace of statutory construction that statutory language should be interpreted according to plain meaning and that like statutory language should be interpreted pari passu, ${ }^{145}$ that doesn't always happen. What we sometimes find is that language borrowed from one statute is interpreted and applied quite differently in the context of another. To paraphrase Jacques Lacan, language can be used to say one thing through saying another. ${ }^{146}$ So even though $\S 4$ of the Clayton Act and $\S 1964$ of the RICO Act share common linguistic material. ${ }^{147}$ Disagreement nonetheless abounds as to the interpretation of each statute in the context of making the determination of who is entitled to sue for

\footnotetext{
${ }^{144}$ Anza v. Ideal Steel Supply Corp., 547 U.S. 451, 457 (2006). For a fuller discussion of this case, see Randy D. Gordon and Samuel E. Joyner, Annual RICO Update, 29 TeX. Bus. LiTiG. J. 24 (2006) and Gordon, Crimes that Count Twice, supra note 1.

${ }^{145}$ In the context of determining the meaning of a statute, "construction" and "interpretation" are disputed terms. One of the main debates is whether judges should consider the legislature's intent. See Cheryl Bodreau et al., Statutory Interpretation and the Intentional(ist) Stance, 38 LoY. L.A.L. REV. 2131, 2131
} (2005) ("[Legal] scholars have pondered whether individuals and collectivities can have intentions; they have asked whether it is possible for judges to discover the legislature's actual intent; and they have questioned whether legislative intent should play a role in judges' interpretations of statutes."). Another huge debate is whether judges should consider a statute's legislative history. See Jonathan R. Siegel, The Use of Legislative History in a System of Separated Powers, 53 VAND. L. REV. 1457, 1458 (2000) ("In the long-running debate over methods of statutory interpretation, no issue receives more attention than legislative history."). Here, for simplicity's sake, I treat the terms synonymously.

${ }^{146}$ See Jacwues Lacan, Function And Field of SPEECH AND LANGAuge (1953).

${ }^{147}$ Agency Holding Corp. v. Malley-Duff \& Associates, Inc., 483 U.S. 143, 150 (1987) ("Even a cursory comparison of the two statutes reveals that the civil action provision of RICO was patterned after the Clayton Act."). Specifically, Section 4 of the Clayton Act provides:

Any person who shall be injured in his business or property by reason of anything forbidden in the antitrust laws may sue therefor in any district court of the United States. . . and shall recover threefold the damages by him sustained, and the cost of suit including a reasonable attorney's fee.

15 U.S.C. $\S 15(a)$. Section 1964(c), RICO’s civil enforcement provision provides: Any person injured in his business or property by reason of a violation of section 1962 of this chapter may sue therefor in any appropriate United States district court and shall recover threefold the damages he sustains and the cost of the suit, including a reasonable attorney's fee. 
particular types of violations and what they're entitled to sue for. ${ }^{148}$ Why might this be?

As I've noted before, the government enforcement and private litigation aims under RICO overlap less than, for instance, they do under the federal antitrust laws, where criminal and civil litigation are both targeting conduct that interferes with open competition. The difference represents something of a division of labor: nowadays, federal enforcement aims its resources at "hard core" violations like price fixing whereas private litigation aims at fields that the government has largely abandoned like tying, boycotts, price discrimination, and exclusive dealing, all of which are easily recognizable as potential antitrust violations. RICO, in contrast, shows two very different faces. Government prosecutions look very much like what one would expect from an anti-Mafia criminal statute: typical indictments target violent crime rings engaged in narcotics distribution, union infiltration, gambling, and so forth. ${ }^{149}$ Private RICO litigation, by contrast, almost never involves stereotypical gangland activity; typical complaints almost always turn on allegations of fraud in business or consumer transactions. ${ }^{150}$

At this point one might ask why antitrust litigation is contained and RICO litigation is not. The superficial, question-begging answer is thatalthough RICO's private-right-of-action provision is modeled on $\S 4$ of the

${ }^{148}$ See e.g, Sedima, S.P.R.L. v. Imrex Co., Inc., 473 U.S. 479, 499-500 (1985) (refusing to require a "racketeering injury" under RICO even though an "antitrust injury" is required for an antitrust violation).

${ }^{149}$ Compare e.g., United States v. Simmons, 923 F.2d 934, 940 (2d Cir. 1991) (involving indictments with 24-counts that included, among other things, "murder, conspiracy to murder, heroin trafficking, and conspiracy to distribute heroin") and United States v. Dote, 150 F. Supp. 2d 935, 940 (N.D. Ill. 2001) (involving an indictment that "allege[d] a sequence of gambling offenses") with Sedima, 473 U.S. at 484 (involving counts of mail and wire fraud).

${ }^{150}$ See Gordon, Rethinking Civil Rico, supra note 1, at 323 n.20

See Wal-Mart Stores, Inc. v. Watson, 94 F. Supp. 2d 1027, 1031

(W.D. Ark. 2000). (““[A] high percentage of civil RICO cases, unlike typical antitrust cases, involve fraud claims." (quoting Klehr v. A.O. Smith Corp., 521 U.S. 179, 191(1997)). As of 1985 , "of the 270 known civil RICO cases at the trial court level, $40 \%$ involved securities fraud, $37 \%$ common-law fraud in a commercial or business setting, and only $9 \%$ 'allegations of criminal activity of a type generally associated with professional criminals." Sedima, 473 U.S. at 499 n.16 (quoting ABA SECTION OF CORP., BANKING, \& BUS. LAW, REPORT OF THE AD HOC CIVIL RICO TASK FORCE 55-56 (1985)). Additionally, "[r] oughly two fifths [sic] of all civil actions under RICO are based on charges that the defendant committed mail or wire fraud." Horace D. Nalle, Jr., Civil RICO Claims Predicated on Mail or Wire Fraud: The Indispensability of Reliance, 109 BANKING L.J. 272, 272 (1992). 
Clayton Act - courts sometimes read the two provisions quite differently. As we saw in Brunswick, the Court burdened private plaintiffs with a novel proof requirement, "antitrust injury," that weakened one track of the parallel government/private attorney general paradigm. ${ }^{151}$ Again, lower courts once similarly glossed $\S 1964$ (c) and required proof of "racketeering injury,"152 a constraint that Sedima removed. ${ }^{153}$ But as we saw in RJR Nabisco, the Court also — depending on factual context — has found ways to read $\S 1964$ (c) more restrictively than $\S 4$. Is there a single key that explains these interpretive inconsistencies? Perhaps not. But as I'll ultimately suggest, a court's sense of RICO's purpose will guide its interpretation and application of the statute.

\section{RICO and the Availability of Equitable Relief}

\section{Wollersheim and the Question of First Impression}

Case law discussions of whether injunctions and other forms of equitable relief ${ }^{154}$ are (or should be) available under RICO generally start

\footnotetext{
${ }^{151}$ Brunswick Corp. v. Pueblo Bowl-O-Mat, Inc, 429 U.S. 477, 489 (1977).

${ }^{152}$ Sedima, S.P.R.L. v. Imrex Co., 741 F.2d 482, 494-503 (2d Cir. 1984), rev'd, 473 U.S. 479 (1985). ("[S]tanding to sue under RICO [is not] limited only to people who have standing to sue for a competitive injury under the antitrust laws. ... For purposes of clarity, it is better to identify the RICO standing requirement as a 'racketeering injury' requirement rather than a 'competitive injury' requirement ...").

${ }^{153}$ Sedima, 473 U.S. at 495 ("There is no room in the statutory language for an additional, amorphous 'racketeering injury' requirement.").

${ }^{154}$ An interesting, though rarely discussed, issue is whether declaratory relief is available in a RICO case. The Declaratory Judgment Act, 28 U.S.C. § 2201, states that "[i]n a case of actual controversy within its jurisdiction . . . any court . . . may declare the rights and other legal relations of any interested party ...." One might think that this statute would provide a basis for seeking declaratory relief independent of what's provided in the RICO statute itself, but the few cases addressing the issue do not bear that out. Instead, the cases treat a declaration as-if it were an injunction and either allow or deny declaratory relief for the same reasons that an injunction would be allowed or denied. See Am. Med. Ass'nv. United Healthcare Corp., 588 F. Supp. 2d 432, 446 (S.D.N.Y. 2008) ("Based upon the weight of Second Circuit authority and Congress's failure to address the issue within the statutory language itself, this Court will not infer that the right to injunctive and declaratory relief exists for private litigants under Section 1964 of RICO.”); Aarona v. Unity House Inc., No. 05-00197, 2007 WL 1963701, at *1617 (D. Haw. July 2, 2007) (finding that declaratory relief is not available to a private party after acknowledging that the Ninth Circuit has prohibited injunctive relief but has not addressed declaratory relief); Johnson v. Collins Entm't Co., Inc., 199 F.3d 710, 726 (4th Cir. 1999) ("There is substantial doubt whether RICO grants private parties . . . a cause of action for equitable relief. This doubt is especially acute in light of the fact that Congress has declined to authorize injunctive remedies for private parties." (internal citations and quotations omitted)); Galaxy Distrib., Inc. v. Standard Distrib., Inc., No. 2:15-cv-04273, 2015 WL
} 
with an examination of Religious Technology Center v. Wollersheim. ${ }^{155}$ In that case, the court held that RICO does not afford injunctive relief to private plaintiffs. $^{156}$ To reach this conclusion, the court pursed four lines of argument: namely, linguistic/structural, historical, analogical, and doctrinal. Each of these bears some analysis.

All the arguments run against a common backdrop: $\S 1964(\mathrm{a})$ is a broad grant of equitable jurisdiction to federal courts; $\S$ 1964(b) allows the government to seek equitable remedies; and § 1964(c) allows private plaintiffs to recover treble damages, costs, and fees. ${ }^{157}$ Plainly, then, "[i]n contrast to part (b), there is no express authority to private plaintiffs to seek the equitable relief available under part (a)." 158 But the court quickly conceded the truth of the aphorism that even a flat pancake has two sides: "Admittedly, part (c) also does not expressly limit plaintiffs 'only' two enumerated remedies, nor does part (a) expressly limit the availability of the illustrative equitable remedies to the government." 159 With no clear path forward, the court turned to an evaluation of the arguments that the plaintiff urged.

With respect to linguistic/structural arguments, the court looked at two alternatives. The first was a straight-up grammatical/word choice appeal: "the [plaintiff] suggests that it is significant that the treble damage clause of section 1964(c) is preceded by 'and' rather than 'to,"' which means that all

4366158, at*5 (S.D.W. Va. July 16, 2015) ("RICO does not provide for [the plaintiff's] requested relief of declaratory judgment and permanent/preliminary injunctions"); In re Managed Care Litig., 298 F. Supp. 2d 1259, 1282-83 (S.D.

Fla. 2003) (finding the reasoning in Nat'l Org. For Women, Inc. v. Scheidler, 267 F.3d 687 (7th Cir. 2001) persuasive to authorize both injunctive and declaratory relief); Miller v. Affiliated Fin. Corp., 600 F. Supp. 987, 994 (N.D. Ill. 1984) (finding that "there is nothing in the language, structure or legislative history of private civil RICO to suggest Section 1964(c) was meant to grant private plaintiffs" declaratory and injunctive relief).

The same may be said of other remedies of an equitable or quasi-equitable nature. Russello v. United States, 464 U.S. 16, 22-24 (1983) (concluding that some things are forfeitable under some RICO subsections that are not forfeitable under others); United States v. Philips Morris USA, Inc., 396 F.3d 1190, 1200 (D.C. Cir. 2005) (finding that RICO does not explicitly include disgorgement and therefore it is not available to the Government); United States v. Carson, 52 F.3d 1173, 1182 (2d Cir. 1995) (holding that the availability of disgorgement is limited to the cases where there is a finding "that the gains are being used to fund or promote the illegal conduct, or constitute capital available for that purpose").

${ }^{155}$ Religious Technology Center v. Wollersheim, 796 F.2d 1076 (9th Cir. 1986).

${ }^{156} \mathrm{Id}$. at 1088 ("Taken together, the legislative history and statutory language suggest overwhelmingly that no private equitable action should be implied under civil RICO.").

${ }^{157}$ Id. at 1082; 18 U.S.C. $§ 1964(b)-(c)$ (2016).

158 Wollersheim, 796 F.2d at 1082.

${ }^{159} \mathrm{Id}$. at $1082-83$. 
the equitable remedies of part (a) are imported into the private-party recovery basket. ${ }^{160}$ This reading apparently originated with Professor Blakey, who elaborated on it thusly:

The plain language of subsection (c) reads that a person injured "may sue ... and shall recover." The language does not read "may sue . . . to recover." Because the usual assumption is that legislative purpose is expressed by the ordinary meaning of the words, and the word "and" means "in addition to" or "along with," and the "and" proceeding "shall recover" indicates that the language following is not to be read restrictively, as it would if "to" proceeded "may sue." Accordingly, all necessary and appropriate relief ought to be held to be included in subsection (c). Recovery of treble damages, costs, and attorney fees that follow the "and" are explicitly added to the right to sue for all usual forms of relief. Indeed, nothing in subsection (c) says that they are the only relief that a person may recover. ${ }^{161}$

This reading is not wholly implausible but it is relatively small beer and, in fairness to the court, others had found the argument "rather remarkable" and - even more pointedly_ " "bizarre and wholly unconvincing as a matter of plain English and the normal use of language."162

More convincingly, the plaintiff pointed to variations in language between parts (a) and (b), specifically highlighting that part (a) is general in scope with no apparent restrictions as to who may invoke the enumerated remedies, whereas part (b) allows the Attorney General to seek temporary equitable relief and to do so in derogation of traditional equity principles like the need to show irreparable harm, inadequacy of legal remedies, or victimonly standing. ${ }^{163}$ So read, "part (a) [is] sufficient for a federal court to grant and injunction to a private RICO plaintiff even if Part (c) had never been added to section 1964."164 The court agreed that this interpretation "is certainly a plausible reading of the statutory language." ${ }^{165}$ But the court didn't end there: "our review of Congress' intent in enacting civil RICO convinces us that the [plaintiff] is incorrect. The legislative history mandates us to hold that injunctive relief is not available to a private party in a civil RICO action."166

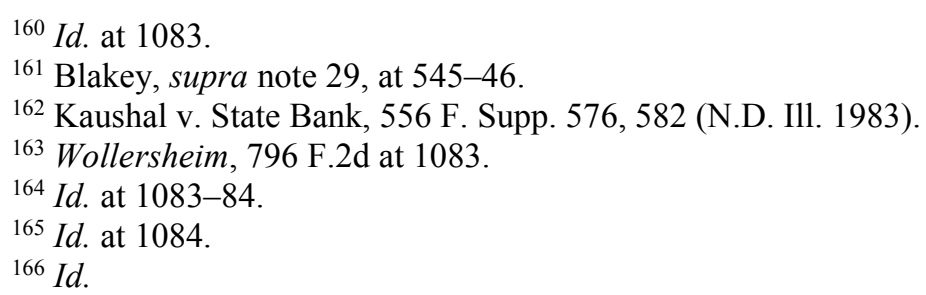


Although RICO commentary is threaded with disagreements over the statute's scope and purpose, one thing everyone can agree on is that its legislative history is long, complicated, and-in many respectscontradictory. On the issue of injunctions, the Wollersheim court began by piecing together RICO's legislative lineage. ${ }^{167}$ Working backwards in time, the Organized Crime Control Act of 1970, of which RICO is Title IX, was derived from S. 30. ${ }^{168}$ The Senate added this Title to S. 30. Nonetheless, the substance of Title IX appears in an earlier Senate bill, S. $1861 .{ }^{169}$ Neither of these predecessor bills contained a private civil cause of action, although an even earlier predecessor, S. 1623, did contain a private cause of action closely tracking the Clayton Act and, accordingly, provided explicitly for treble damages and injunctive relief. ${ }^{170}$ But that was not the end of the trail because that bill was patterned on two Senate bills from an earlier Congress, S. 2048 and S. 2049, both of which provided for private actions similar to those provided in S. 1623. ${ }^{171}$ As the Wollersheim court read this bill shuffling, "the Senate Subcommittee on Criminal Laws and Procedures of the Senate Committee on the Judiciary replaced S. 1623 with S. 1861 apparently in part because S. 1861 provided broader governmental civil relief, such as the investigative demand, and was in other ways a more comprehensive bill."172

The Wollersheim court also looked at parallel actions in the House, especially H.R. 19215, which included a robust civil-claim provision that explicitly provided for private-party injunctions. ${ }^{173}$ Even more important than the House bills, though, was that $\S 1964(\mathrm{c})$ originated in the House as an amendment to S. 30. ${ }^{174}$ The House Judiciary hearings on S. 30 reveal the deep connection between $\S 1964(c)$ and $\S 4$ of the Clayton Act. In those

\footnotetext{
${ }^{167}$ Id. at $1084-88$.

168 Wollersheim, at 1084 (citing S. 30, 91st Cong., 1st Sess., 115 CONG. REC. 769 (1969)); see also G. Robert Blakey, Racketeer Influenced and Corrupt Organizations (RICO): Basic Concepts-Criminal and Civil, 53 TEMP. L.Q. 1009, 1017 (1980) ("In 1969, Senator John L. McClellan, in response to his longstanding interest in organized crime, introduced Senate bill 30, which was based on a number of the recommendations of the President's Crime Commission.").

${ }^{169}$ Id. (citing S. 1861, 91st Cong., 1st Sess., 115 CONG. REC. 9, 568-71 (1969); see also 116 CONG. REC.

591 (remarks of Sen. McClellan)).

${ }^{170}$ Id. (citing S. 1623, 91st Cong., 1st Sess., 115 CONG. REC. 6, 995-96 (1969); S. 1623, 91st Cong., 1st Sess. §§ 3(c), 4(a) (1969)).

${ }^{171}$ Id. (citing 90th Cong., 1st Sess. (1967); Belgard, Private Civil RICO Plaintiffs Are Entitled to Equitable Relief under \& 1964(a), 2 RICO L. REP. 537, 538 (quoting relevant provisions of these bills)).

${ }^{172}$ Wollersheim, 796 F.2d at 1083 (citing Hearings on Measures Relating to Organized Crime Before the Subcommittee on Criminal Laws and Procedures of the Senate Committee on the Judiciary, 91st Cong., 1st Sess. 387-88, 407-08 (1969)).

${ }^{173} \mathrm{Id}$.

${ }^{174}$ See Sedima, S.P.R.L. v. Imrex Co., Inc., 473 U.S. 479, 486-87 (1985),
} 
hearings, Representative Steiger proposed the addition of a treble-damages provision "similar to the private damage remedy found in the antitrust laws. ... [T] hose who have been wronged by organized crime should at least be given access to a legal remedy. In addition, the availability of such a remedy would enhance the effectiveness of title IX's prohibitions." "175 The American Bar Association made a similar Clayton Act- rooted proposal. ${ }^{176}$

Representative Steiger's proposal, as did the passed-over Senate bills noted above, provided a private injunctive remedy under $\S 1964(\mathrm{a}) .{ }^{177} \mathrm{But}$ the statutory language that was ultimately enacted came from H.R. 19586, not H.R. 19215. ${ }^{178}$ As the Wollersheim court conceded, though, the legislative history is silent as to why the subcommittee adopted one formulation over the other. ${ }^{179}$ Nonetheless, where some might see a mere lacuna in the legislative record, the Wollersheim court read an "explicit[] reject[ion of] a private injunctive relief provision." 180

As to the specific issue of whether $\S 1964(\mathrm{c})$ merely adds another remedy to those made available to all plaintiffs (private or governmental) via $\S$ 1964(a), the court admitted that "[t]he legislative history offers some support for this thesis." 181 This is especially so because-in introducing the bill for House debate - the House sponsor, Representative Poff, stated:

Courts are given broad powers under the title to proceed civilly, using essentially their equitable powers, to reform corrupted organizations, for example, by prohibiting the racketeers to participate any longer in the enterprise, by ordering divestitures, and even by ordering dissolution or reorganization of the enterprise. In addition, at the suggestion of the gentleman from Arizona (Mr. Steiger) and also the American Bar Association and others, the committee has provided that private persons injured by reason of a violation of the title may recover treble damages in Federal courts - another example of the antitrust remedy being adapted for use against organized criminality. ${ }^{182}$

\footnotetext{
175 Wollersheim, 796 F.2d at 1084 (quoting Organized Crime Control: Hearings on S. 30, and related proposals, before Subcommittee No. 5 of the House Committee on the Judiciary, 91st Cong., 2d Sess. 520 (1970) [hereinafter House Hearings].

${ }^{176}$ Id. (quoting House Hearings, supra note 176, at 543-44, 548, 559).

${ }^{177}$ Id. (citing House Hearings, supra note 176, at 521 (subsection (c) of proposal of Rep. Steiger)).

${ }^{178} \mathrm{Id}$. at 1085.

${ }^{179}$ Id. at 1084 (citing 116 CONG. REC. 25, 190 (remarks of Sen. McClellan welcoming House addition of private treble damages remedy)).

180 Wollersheim, 796 F.2d at 1085.

${ }^{181} \mathrm{Id}$.

${ }^{182}$ Id. (emphasis in original) (quoting 116 CONG. REC. 35, 295 (1970)).
} 
Earlier Senate floor debates also drew attention to the value of private equitable relief, as the remarks of Senator McClellan, the bill's principal Senate sponsor, suggest:

Since enactment of the Sherman Antitrust Act in 1890, the courts have used several equitable remedies ... to implement the language of 15 U.S.C. sections 1 and 2. I believe, and numerous others have expressed a similar belief, that these equitable devices can prove effective in cleaning up organizations corrupted by the forces of organized crime. ${ }^{183}$

This wasn't enough to tip the court in favor of equitable relief, though, because "two separate episodes from the history of civil RICO's legislative passage convince us that the conclusions the [plaintiff] would have us draw from these congressional statements do not reflect Congress' intent in section 1964." ${ }^{\prime 84}$ As the court described these two episodes, in the first "the House rejected an amendment, described as 'an additional civil remedy,' which would expressly permit private parties to sue for injunctive relief under section 1964(a)," and in the second, "in the very next year after RICO's enactment, Congress refused to enact a bill to amend section 1964 and give private plaintiffs injunctive relief." 185 Even a quick review of the circumstances surrounding these episodes shows that - although they tell in the direction the court suggests - they are both far from definitive evidence of Congressional intent.

During the House floor debates, Representative Steiger offered an amendment that, in addition to other items, would have allowed private injunctive relief. ${ }^{186}$ But the proposal met with a strong procedural objection from the bill's House sponsor, Representative Poff:

Mr. Chairman, I want to pay special tribute to the gentleman in the well for having raised the issue which his amendment defines. It does offer an additional civil remedy which I think properly might be suited to the special mechanism fashioned in title IX. Indeed, I am an author of an almost identical amendment. It has its counterpart almost in haec verba in the antitrust statutes, and yet I suggest to the gentleman that prudence would dictate that the Judiciary Committee very carefully explore the potential consequences that this new remedy might have in all the ramifications which this legislation contains and for that reason, I would hope that the gentleman might agree to ask unanimous consent to

${ }^{183} I d$. (quoting 116 CONG. REC. 35, 592 (1970)).

${ }^{184} \mathrm{Id}$.

185 Wollersheim, 796 F.2d at 1085.

${ }^{186}$ Id. (citing 116 CONG. REC. 35, 227-28, 346 (1970)). 
withdraw his amendment from consideration with the understanding that it might properly be considered by the Judiciary Committee when the Congress reconvenes following the elections or some other appropriate time. ${ }^{187}$

In response to these remarks, Representative Steiger withdrew his proposal $^{188}$ and, consequently, the House passed the bill with the treble damages provision in the form that the Committee recommended. ${ }^{189}$ The Senate subsequently adopted this version of the bill. ${ }^{190}$

The second incident that the Ninth Circuit found noteworthy is related to the first. That is, in the very next session, a new Senate bill mirroring Representative Steiger's proposed amendment from the previous year was proposed as an amendment to RICO, which was by then an enacted statute. ${ }^{191}$ There is certainly some evidence - in the form of testimony - that the bill "would expand the available civil remedies" because "[n] ow only the United States can institute injunctive proceedings." 192 And when the Senate Judiciary Committee reported favorably on the bill, it noted that the new bill would supplement RICO's treble-damages provision by "authoriz[ing] private injunctive relief from racketeering activity." 193 The record of Senate floor debates on S. 16 contains statements to similar effect. ${ }^{194}$ Ultimately, though, the bill never became law because - although the Senate passed itit did not pass the House. ${ }^{195}$

Somewhat surprisingly, given that one of the episodes failed on procedural grounds and the other is ex post facto, the court found that " $[\mathrm{t}] \mathrm{he}$ clear message from the legislative history is that, in considering civil RICO, Congress was repeatedly presented with the opportunity expressly to include

\footnotetext{
${ }^{187}$ Id. at 1085-86 (emphasis in original) (citing 116 CONG. REC. 35, 346-47 (1970)).

${ }^{188}$ Id. at 1086 (citing 116 CONG. REC. 35, 346-47 (1970)).

${ }^{189}$ Id. (citing 116 CONG. REC. 35, 363-64 (1970)).

${ }^{190}$ Id. (citing 116 CONG. REC. 35, 296 (1970)).

${ }^{191}$ Id. (citing S. 16, 92d Cong., 1st Sess. (1971); Victims of Crime, Hearing before the Subcommittee on Criminal Laws and Procedures of the Senate Committee of the Judiciary, 92d Cong., 1st Sess. 3 (1972)).

${ }^{192}$ Id. (emphasis in original) (citing Victims of Crime, Hearing before the Subcommittee on Criminal Laws and Procedures of the Senate Committee of the Judiciary, 92d Cong., 1st Sess. 158 (1972)) (statement of Richard Velde, Associate Administrator, Law Enforcement Assistance Administration).

${ }^{193}$ Id. (quoting 92d Cong., 2d Sess., 118 CONG. REC. 29, 368-69 (1972); S. REP. No. 1070, at 10 (1972)).

${ }^{194}$ Id. (citing 118 CONG. REC. 29, 370 (1972) (remarks of Senator McClellan) (observing that the bill would expand RICO remedies by "authoriz[ing] private injunctive relief from racketeering activity"); see also S. Rep. No. 1070, at 10 (1972)).

${ }^{195}$ Wollersheim, 796 F.2d at 1086.
} 
a provision permitting private plaintiffs to secure injunctive relief. On each occasion, Congress rejected the addition of any such provision." ${ }^{296}$ We'll return to this conclusion in a bit, but suffice it for now to pass over the finding of "clarity" with a notation of "not really."

The court then turned to an argument by analogy, finding that "[ $\mathrm{t}] \mathrm{his}$ clear message is reinforced by recalling that civil RICO was intended to provide a private cause of action modeled on the analogous provision of the antitrust laws." 197 To make this point, the court first returned to legislative history and established the link between $\S 1964(\mathrm{c})$ and $\S 4 .{ }^{198}$ The Court then cited two old antitrust cases for the proposition that $\S 4$ precludes private injunctive relief, which is available under $\S 16$ of the Clayton Act. ${ }^{199}$ And since RICO has no analogue to $\S 16$, Congress must have consciously declined to bring the antitrust-RICO analogy full circle. ${ }^{200}$ But for support, the court referred again to the legislative history discussed above, which introduces a circularity of another sort. ${ }^{201}$

Finally, the court resorted to the general proposition that courts should not imply claims and remedies into comprehensive statutory schemes. But this argument, too, was ultimately grounded in the appeal to legislative history: "For civil RICO, there are strong indicia of congressional intent against any implied injunctive relief remedy. Similarly, there is no indication in the language of section 1964 that civil RICO was not intended, as its plain wording states, to limit private plaintiffs only to damages, costs, and fees. Taken together, the legislative history and statutory language suggest overwhelmingly that no private equitable action should be implied under civil RICO." 202

\footnotetext{
${ }^{196} I d$.

${ }^{197} \mathrm{Id}$.

${ }^{198}$ Id. at 1086-1087. In support the court cited: 116 CONG. REC. 592, 602 (remarks of Sen. McClellan and Sen. Hruska, respectively); S. REP. No. 617, 80-82, 125, 160 (1969); U.S. Code Cong. \& Admin. News 1970, p. 4007; 116 CONG. REC. 35, 295 (Private treble damages provision is "another example of the antitrust remedy being adapted for use against organized criminality.”) (remarks of Rep. Poff); House Hearings, supra note 176, at 543-44 (testimony of ABA President Wright); see Sedima, S.P.R.L. v. Imrex Co., Inc., 473 U.S. 479, 489 (1985). ("The clearest current in [the legislative] history is the reliance on the Clayton Act model ...").

${ }^{199}$ Wollersheim, 796 F.2d at 1087 (citing Paine Lumber Co., Ltd. v. Neal, 244 U.S. 459, 471 (1917); Minnesota v. N. Sec. Co., 194 U.S. 48, 70-71 (1904)). ${ }^{200} \mathrm{Id}$.

${ }^{201} I d$. (noting that [the fact] " $[\mathrm{t}]$ hat it did not [complete the analogy], despite the repeated efforts of several members of Congress, strongly suggests that Congress did not intend to give private civil RICO plaintiffs access to equitable remedies."). ${ }^{202} I d$. at 1088.
} 
Despite this appeal to the "overwhelming" nature of the evidence buttressing its conclusion, the court ended on several notes of equivocation:

- "In reaching this conclusion, we recognize that strong policy arguments can be made to support a right to injunctive relief for private RICO plaintiffs."203

- "It may be that in drawing the line between private equitable relief and private damages, Congress wished to preclude federal courts from interfering with the dayto-day running of businesses at the behest of what might be only a disgruntled competitor. However, this same concern about anticompetitive litigation has been frequently leveled at RICO's treble damages provision. The Supreme Court, despite expressing sympathy for this concern, has rejected it as not consistent with the statute's wording and history." 204

- We recognize the force of the [plaintiff's] argument that a private injunctive remedy would permit an injured party to put an immediate stop to racketeering behavior that threatens his or her business with economic destruction before the business has been brought to its knees. While the treble damages remedy is a potent weapon, it necessarily assumes that economic injury has occurred. The preventive effect of injunctive relief is often a more just remedy. Although civil RICO empowers the government to bring an injunctive suit to protect a threatened enterprise, we recognize that the resources of the United States Attorney's office are limited. Civil RICO deliberately created dual avenues of enforcement-private and public. We recognize that precluding enforcing parties from employing the weapon of equitable relief partially hamstrings the statute's effect. 'Private attorney general provisions such as Sec. 1964(c) are in part designed to fill prosecutorial gaps,' and use of equitable remedies by private parties would frequently result in substantial benefits to society generally. These broad social benefits, such as the dismantling of an illegitimate enterprise, would generally exceed the gain to the private plaintiff from this action, especially where the

\footnotetext{
${ }^{203} I d$.

${ }^{204}$ Wollersheim, 796 F.2d at 1088.
} 
individual's injury has been ameliorated by treble damages. ${ }^{205}$

In the end, the court's opinion stands as an excellent example of the post-structuralist observation that all texts - especially those with pretentions to authority - inevitably tend to undermine themselves. ${ }^{206}$

\section{Life after Wollersheim}

The flimsy basis of the Ninth Circuit's holding met with outright hostility a few years later in National Organization For Women, Inc. v. Scheider, which has grown to serve as the leading counterweight to Wollersheim. ${ }^{207}$ There, the court began by anchoring Wollersheim in the early days of RICO jurisprudence, noting that the Ninth Circuit was the only circuit court to have directly addressed the issue of RICO injunctions, ${ }^{208}$ and emphasizing that Wollersheim reached its conclusion by "relying largely on [its] reading of the statute's legislative history." 209 From this baseline, the court concluded that Wollersheim suffered from several deficiencies: "Our study of Supreme Court decisions since the 1986 Wollersheim opinion convinces us that the approach of the Ninth Circuit (which relied almost exclusively on the legislative history of RICO to reach its result, as opposed to the actual language of the statute) no longer conforms to the Court's present jurisprudence, assuming for the sake of argument that it was a permissible one at the time." ${ }^{210}$ So the court set out to show how the question could be answered on a purely textual level: "In interpreting the remedial provisions of the RICO statute, our inquiry begins with the statute's text, and,

\footnotetext{
${ }^{205} \mathrm{Id}$. at $1088-89$.

${ }^{206}$ See Jacques Derrida, The Politics of Friendship, 85 J. PHIL. 632, 632 (1988)

(describing the various contradictions in the statement "[oh] my friends, there is no friend").

${ }^{207}$ Nat'l Org. For Women, Inc. v. Scheidler, 267 F.3d 687, 699 (7th Cir. 2001), rev'd on other grounds, 537 U.S. 393 (2003) [hereinafter NOW].

${ }^{208}$ According to the Seventh Circuit, the other circuit opinions, pro and con, had addressed the matter only tangentially and in dicta:
}

Compare Johnson v. Collins Ent[m't]. Co., 199 F.3d 710, 726

(4th Cir. 1999), In re Fredeman Litig., 843 F.2d 821, 828-30 (5th

Cir. 1988), and Trane Co. v. O'Connor Sec., 718 F.2d 26, 28-29

(2d Cir. 1983) (expressing doubt about availability of injunctive relief for private plaintiffs), with Bennett v. Berg, 710 F.2d 1361, 1366 (8th Cir. 1983) (McMillan, J., concurring) (suggesting injunctive relief is available); see also Lincoln House, Inc. v. Dupre, 903 F.2d 845, 848 (1st Cir. 1990)[;] N[e.] Women's Ctr. v. McMonagle, 868 F.2d 1342, 1355 (3d Cir. 1989) (noting controversy but expressing no opinion on resolution).

NOW, 267 F.3d at 695 (emphasis added).

${ }^{209} \mathrm{Id}$.

${ }^{210} I d$. 
if the text is unambiguous, it ends there as well." ${ }^{211}$ The court began with a brief summary of the competing interpretive positions. Under the first position, "[s] ection 1964(a) . . . grants the district courts jurisdiction to hear RICO claims and also sets out general remedies, including injunctive relief, that all plaintiffs authorized to bring suit may seek."212 Section 1964(b) provides that the Attorney General will publicly enforce the statute and "specifies additional remedies, all in the nature of interim relief, that the government may seek." ${ }^{213}$ Section 1964(c) also adds to $\S$ 1964(a), but this time by granting private plaintiffs a right to sue for treble damages. ${ }^{214}$ "[T] reading of the statute gives the words their natural meaning and gives effect to every provision in the statute." 215

Taking the court's initial remarks as a pointer to readers, it's not shocking that - from the outset - the court branded the Wollersheim view "a less intuitive interpretation." ${ }^{216}$ Under that interpretation, $\S 1964(a)$ is merely a jurisdictional grant authorizing district courts to hear civil RICO claims "and to grant injunctions to parties authorized by other provisions of the law to seek that form of relief." 217 Section 1964(b), then, allows the Attorney General to institute RICO proceedings and authorizes the government to seek the relief stated there, as well as the relief described in $\S 1964(\mathrm{a}){ }^{218}$ This leaves $\S 1964$ (c) to provide a limited right of action for private parties. ${ }^{219} \mathrm{But}$ the Wollersheim rubric requires the two clauses of $\S 1964$ (c) to be read "as tightly linked provisions, under which private plaintiffs may sue only for monetary damages. The mention of this type of relief in the second clause must mean ... that by implication no other remedies, particularly injunctive remedies, are available." ${ }^{220}$ Because of the linguistic twists required to follow this interpretive trail, the court declined to "agree that this is a reasonable reading of the statute" and set out to dismantle Wollersheim step-by- step. ${ }^{221}$

First, the court suggested that Wollersheim is grounded on a misreading of $\S 1964(\mathrm{~b}){ }^{222}$ This is so because Wollersheim concludes that $\S$ 1964(b) explicitly "permits the government to bring actions for equitable relief." 223 What $\S 1964$ (b) actually provides, though, is for the government to

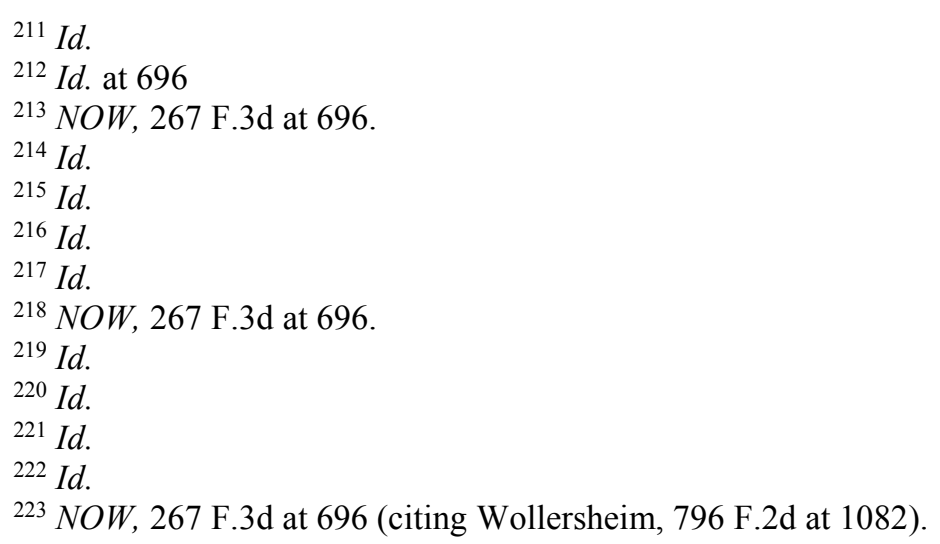


seek a special form of equitable relief - namely, interim relief. ${ }^{224}$ And since no one doubts that the government can seek and obtain a permanent injunction, that authority must come from somewhere else. Where else? Section 1964(a). Structurally, then, "[t]he sentence ' $[\mathrm{t}]$ he Attorney General may institute proceedings under this section' is in that respect the equivalent of the first clause in $\S 1964(\mathrm{c})$, which says '[a]ny person injured in his business or property by reason of a violation of section 1962 of this chapter may sue therefor in any appropriate United States district court. . . ' Neither one addresses what remedy the plaintiff may seek." 225 Cast in this light, "the government's authority to seek injunctions comes from the combination of the grant of a right of action to the Attorney General in $\S$ 1964(b) and the grant of district court authority to enter injunctions in $\S 1964(\mathrm{a})$, we see no reason not to conclude, by parity of reasoning, that private parties can also seek injunctions under the combination of grants in $\S \S 1964(\mathrm{a})$ and (c).,"226

The Seventh Circuit also challenged the Ninth Circuit's claim that $\S$ 1964(a) is purely "jurisdictional" in nature: "What $§ 1964(a)$ does is to grant district courts authority to hear RICO claims and then to spell out a nonexclusive list of the remedies district courts are empowered to provide in such cases." 227 To firm up this point, the court analogized $\S 1964$ (a) to a "strikingly similar" statute that the Supreme Court construed in Steel Co. v. Citizens for a Better Environment, 523 U.S. 83, 90 (1998). ${ }^{228}$ In that case, the statute at issue provided that "[ $\mathrm{t}]$ he district court shall have jurisdiction in actions brought under subsection (a) of this section against an owner or operator of a facility to enforce the requirement concerned and to impose any civil penalty provided for violation of that requirement."229 The Supreme Court, operating from the premise that "[ij]urisdiction' . . . is a word of many, too many, meanings," held that it would be "unreasonable to read [the statute] as making all the elements of the cause of action under subsection (a) jurisdictional, rather than as merely specifying the remedial powers of the court, viz., to enforce the violated requirement and to impose civil penalties." 230 The Seventh Circuit found that this rationale is just as applicable to RICO and that, therefore, $\S$ 1964(a) both confers jurisdiction on the district courts and specifies certain remedial powers that the courts will have in cases brought before them. ${ }^{231}$

Once that point was established, the court found that a Wollersheimtype reading of the statute necessarily collapsed under the pressure of basic

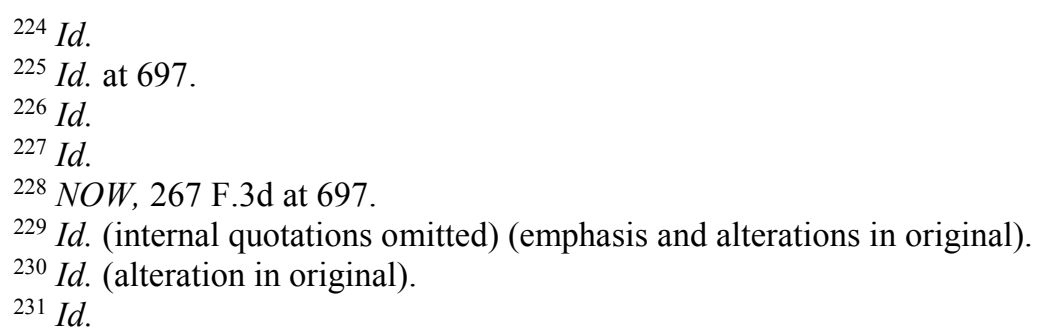


canons of construction. Under the Wollersheim reading, "injunctive relief is not available to any particular plaintiff unless it is also provided by some other section of the statute. This reading renders $\S 1964(\mathrm{a})$ 's provision for injunctive relief a nullity." 232 But "[b]ecause an alternative reading exists which gives meaning to every section of the statute," the Wollersheim approach must fail. ${ }^{233}$

Finally, with respect to statutory interpretation, the court found that two sources of interpretive authority validated its approach. First, it noted that its "interpretation is consistent with Congress's admonition that the RICO statute is to be 'liberally construed to effectuate its remedial purposes," "234 an admonition institutionalized in a then-recent series of Supreme Court cases. ${ }^{235}$ Second, it suggested that its "interpretation of $\S$ 1964 is also in keeping with the underlying purposes of the RICO statute."236 For as the Supreme Court had already found, Congress, in enacting RICO, intended to "encourag[e] civil litigation to supplement Government efforts to deter and penalize the ... prohibited practices. The object of civil RICO is

${ }^{232} I d$

${ }^{233}$ NOW, 267 F.3d at 697. The Seventh Circuit also rejected Wollersheim's invocation of the maxim "where a statute expressly provides a particular remedy or remedies, a court must be chary of reading others into it." Id. at 697-98; see also Religious Tech. Ctr. v. Wollersheim, 796 F.2d 1076, 1088 (9th Cir. 1986) (quoting Transamerica Mortg. Advisors, Inc. v. Lewis, 444 U.S. 11, 19 (1979)). The court observed that

While we have no doubt that this is good advice as a general matter, we do not find it particularly helpful in this case. This is not a situation in which Congress has provided for a private damages remedy and has remained silent as to the availability of injunctive relief. Instead, Congress explicitly provided for injunctive relief in $\S 1964(\mathrm{a})$, although it did not specify in that section which plaintiffs can seek such relief. Given that the next two sections describe two types of plaintiffs, the government and private plaintiffs, and spell out additional remedies specific to each type, we find that the only logical conclusion is that Congress intended the general remedies explicitly granted in $\S$ 1964(a) to be available to all plaintiffs.

NOW, $267 \mathrm{~F} .3 \mathrm{~d}$ at 698.

${ }^{234}$ NOW, 267 F.3d at 698; see also Organized Crime Control Act of 1970, Pub. L. No. 91-452, 84 Stat. 922.

${ }^{235}$ Reves v. Ernst \& Young, 507 U.S. 170, 183 (1993); Salinas v. United States, 522 U.S. 52, 61-66 (1997); Nat'l Org. For Women, Inc. v. Scheidler, 510 U.S. 249, 256-62 (1994) (rejecting requirement that enterprise have an economic motive); Sedima, S.P.R.L. v. Imrex Co., Inc., 473 U.S. 479, 498 (1985); United States v. Turkette, 452 U.S. 576, 587 (1981). The court also noted the Supreme Court's position that the liberal-construction clause should have particular force in construing $\S 1964$ because it is there that "RICO's remedial purposes are most evident." Sedima, 473 U.S. at 491 n.10.

${ }^{236}$ NOW, 267 F.3d at 698. 
thus not merely to compensate victims but to turn them into prosecutors, 'private attorneys general,' dedicated to eliminating racketeering activity."237 The court thus concluded that allowing injunctive relief to private plaintiffs is fully consistent with the liberal-construction and statutory-purpose principles surrounding RICO's adoption and prior applications. ${ }^{238}$

Although the court indicated that it "would be confident resting [its] holding purely on the plain text of $\S 1964$," it nonetheless felt compelled to demolish Wollersheim's appeal to legislative history. ${ }^{239}$ Indeed, in a pointed swipe, the court suggested a measure of disingenuousness in the Wollersheim court's analysis: "Perhaps realizing that the plain text of the statute strongly suggests that private plaintiffs can seek injunctions, the Wollersheim court relied heavily in its decision on two pieces of legislative history." ${ }^{240}$ With respect to these two "snippets of legislative history," the court observed that they are at best equivocal on the point of private injunctions and that contradictory indicia may be found in the legislative history, as Wollersheim conceded. ${ }^{241}$ As such, the court concluded that the legislative history did not constitute the sort of "clearly expressed legislative intent" necessary to "cast doubt on unambiguous statutory language." 242 But more important, even if the Wollersheim court "made a reasonable decision in 1986 to rely on Congress's refusal to enact amendments to the statute, recent Supreme Court precedent teaches that this type of legislative history is a particularly thin reed on which to rest the interpretation of a statute." 243 So, in accordance with a more skeptical view of legislative history, the court concluded that the proffered legislative history could not trump otherwise plain statutory language. ${ }^{244}$

\footnotetext{
${ }^{237} I d$. (alteration in original) (quoting Rotella v. Wood, 528 U.S. 549, 557 (2000)).

${ }^{238} I d$.

${ }^{239} I d$. at 698.

${ }^{240} I d$. at 699.

${ }^{241}$ NOW, 267 F.3d at 699.

${ }^{242} I d$. In an opinion issued shortly after NOW, Judge Rakoff opined that - whether or not the statute is "unambiguous"-Wollersheim gave no reasons to overcome "the normal presumption favoring a court's retention of all powers granted by the Judiciary Act of 1789," which includes "equity jurisdiction." Motorola Credit Corp. v. Uzan, 202 F. Supp. 2d 239, 244 (S.D.N.Y. 2002).

${ }^{243}$ NOW, 267 F.3d at 699 (citing Solid Waste Agency v. U.S. Army Corps of Eng'rs, 531 U.S. 159, 169-70 (2001) ("Failed legislative proposals are a particularly dangerous ground on which to rest an interpretation of a prior statute. A bill can be proposed for any number of reasons, and it can be rejected for just as many others."); Cent. Bank v. First Interstate Bank, 511 U.S. 164, 187 (1994) ("Congressional inaction lacks persuasive significance because several equally tenable inferences may be drawn from such inaction, including the inference that the existing legislation already incorporated the offered change.").

${ }^{244} I d$.
} 
In what the court described as a "last effort" to save the Wollersheim statutory construction, it examined the argument that structural differences between RICO and the Clayton Act "demand the inference that no private right to injunctive relief exists under RICO." 245 This line of argument is based on the Clayton Act spreading private rights of action across two sections (damages in $\S 4,15$ U.S.C. $\S 15$ (a), injunctions in $\S 16,15$ U.S.C. $\S 26$ ), whereas RICO contains only one section addressing private remedies and that subsection mentions only damages. This gap is taken to mean that Congress did not intend to allow private-party injunctions. ${ }^{246}$

The court rejected this line of analysis for three reasons. "First, the mere fact that the Clayton Act spreads its remedial provisions over a number of different sections of the U.S. Code, and RICO does not, adds little to our understanding of either statute." ${ }^{247}$ Second, "the Supreme Court regularly treats the remedial sections of RICO and the Clayton Act identically, regardless of superficial differences in language." 248 Third, "[s]ince the Court has already determined that litigants other than the Attorney General may obtain broad injunctive relief under the Clayton Act, cases like Klehr and Holmes indicate that we ought to adopt the same interpretation with respect to RICO." ${ }^{249}$ Fourth, a post-Wollersheim Supreme Court case, American Stores, "(which came to the Court from the Ninth Circuit) pointedly rejected the way in which the Ninth Circuit had relied on legislative history to limit the Clayton Act's textual grant of private injunctive relief," thereby undercutting Wollersheim, "which had used the same methodology as the discredited American Stores opinion." 250

With all the Wollersheim arguments dispatched to its satisfaction, the court held that " $\$ 1964$ authorizes injunctive relief at the behest of both the Attorney General and private plaintiffs, authorizes interim measures when the Attorney General sues, and authorizes private treble damages only for private plaintiffs (and not the United States).,"251

As things now stand (i.e., with the Supreme Court yet to weigh in), courts that are left to decide the question of whether private parties may seek injunctions essentially have three choices: follow Wollersheim or $N O W$, or find a way to avoid the issue. After Wollersheim (and even to date), the majority of courts to take up the question have followed Wollersheim. But

\footnotetext{
${ }^{245} I d$.

${ }^{246} I d$. at $699-700$.

${ }^{247}$ Id. at 700.

${ }^{248}$ NOW, 267 F.3d at 700 (citing Klehr v. A.O. Smith Corp., 521 U.S. 179, 188-89

(1997) (applying Clayton Act rule for accrual of cause of action to RICO); Holmes v. SIPC, 503 U.S. 258, 267 (1992) (applying proximate cause rule to RICO)).

${ }^{249} \mathrm{Id}$.

${ }^{250}$ Id. (citing California v. Am. Stores Co., 495 U.S. 271 (1990)).

${ }^{251} \mathrm{Id}$.
} 
this data point does not mean that a consensus quickly hardened or that there is now a prevailing view. ${ }^{252}$ As one district court recently and astutely noted, "it is impossible to discern whether these courts chose to follow the Ninth Circuit's position simply because it was the only pronouncement on this issue or because the Ninth Circuit's logic is more persuasive than the Seventh Circuit's." ${ }^{253}$ And it's worth noting that a significant fraction of the courts following Wollersheim were bound to it (because they're in the Ninth Circuit) ${ }^{254}$ or-though following Wollersheim on the narrow point of injunctive relief under $\S 1964$-nonetheless found alternative ways to permit injunctions in RICO cases. ${ }^{255}$

${ }^{252}$ As I already noted, the leading commentator, Professor G. Robert Blakey, sharply criticized the Wollershiem opinion at the time and has continued the drumbeat as recently as October 2014, in connection with Chevron v. Donziger.

Brief for Professor G. Robert Blakey as Amici Curiae Supporting Appellant at *10, 14, Chevron Corp. v. Donziger, 833 F.3d 74 (2d Cir. 2016) ("This amicus agrees with the Seventh Circuit's opinion in Scheidler that private parties have the power to obtain the full range of equable remedies... . Scheidler is correctly decided ....").

${ }^{253}$ Huyer v. Wells Fargo \& Co., 295 F.R.D. 332, 344 (S.D. Iowa 2013). Of course, following an institutionalized interpretation is a legitimate tool. See MACCORMICK, supra note 9. But, as we saw above, it's only one of many.

${ }^{254}$ See, Cohen v. Trump, 200 F. Supp. 3d 1063, 1069 (S.D. Cal. 2016); Aarona v. Unity House Inc., No. 05- 00197, 2007 WL 1963701 (D. Haw. July 2, 2007); Holmes High Rustler, LLC v. Gomez, No. 15-cv-02086-JSC, 2015 WL 4999737 (N.D. Cal. Aug. 21, 2015); State Comp. Ins. Fund v. Khan, No. 12-01072-CJC, 2012 WL 12887395 (C.D. Cal. Dec. 28, 2012); Comm. to Protect our Agric. Water v. Occidental Oil \& Gas Corp., No. 1:15-01323-DAD-JLT, 2017 WL 272215 (E.D. Cal. Jan 20, 2017).

${ }^{255}$ Raymark Indus., Inc. v. Stemple, 714 F. Supp. 460, 476 (D. Kan. 1988) (noting that it found Wollersheim persuasive, but the plaintiff also sought injunctive relief under its common-law claims); Ne. Women's Ctr., Inc. v. McMonagle, 868 F.2d 1342, 1355 (3d Cir. 1989) (deciding not to reach the issue of injunctive relief under RICO because the plaintiff's state-law claims also provided for injunctive relief).

Hawaii's "baby" RICO statute, allowing equitable relief, states:

The circuit courts of the State shall have jurisdiction to prevent and restrain violations of this chapter by issuing appropriate orders, including, but not limited to: ordering any person to divest oneself of any interest, direct or indirect, in any enterprise; imposing reasonable restrictions on the future activities or investments of any person, including, but not limited to, prohibiting any person from engaging in the same type of endeavor as the enterprise engaged in, or ordering dissolution or reorganization of any enterprise, making due provision for the rights of innocent persons.

HAW. REV. StAT. § 842-8(a) (1984); see also Del. CodE ANN. tit. 11, § 1505(a) (West 1995) (same); V.I. CODE ANN. tit. 14, § 607 (1990) (providing a similar "baby" RICO statute to Hawaii's with slightly different wording); MISS. CODE 
If there was a growing sense in the years after $N O W$ that Wollersheim was misguided in its analysis of the RICO statute, the correctness of that sense was recently confirmed in Chevron v. Donziger. ${ }^{256}$ That case, which grew out of well publicized claims that an attorney and others had procured a multi-billion dollar, environmental- damage judgment against Chevron on behalf of several dozen Ecuadorians through a host of illegal acts, had resulted in a trial-court judgment that - among other things - enjoined the defendants from seeking to enforce the Ecuadorian judgment. ${ }^{257}$ The Second Circuit concluded that equitable relief is available under $\S 1964(c)$, "largely for the reasons stated by the Seventh Circuit opinion in NOW I."258 Nonetheless, the Second Circuit supplemented the Seventh Circuit's analysis in a few respects that are worth at least passing notice.

First, the Second Circuit agreed with the Seventh Circuit that $\S$ 1964(a) "neither states that any category of persons may not obtain relief that is within the powers granted to the federal courts nor specifies the persons in whose favor the courts are authorized to exercise the powers there granted." 259 Under this view, then, "Congress did not intend to limit the court's subsection (a) authority by reference to the identity or nature of the plaintiff." 260 In contrast, under this view, subsections (b) and (c) do limit the categories of plaintiffs to whom specified relief is available. Subsection (b) makes "interim relief . . . available only to the United States, not to a private person."261 Subsection (c) allows a "person" to seek treble damages and attorneys' fees, and-because the U.S. is not a "person" under RICO's definition of the term ${ }^{262}$ - the subsection "excludes the federal government from those to whom a court may award treble damages and attorneys' fees." ${ }^{263}$ Accordingly, the court found that subsections (b) and (c) contain categorical limitations as to whom specified relief is available, but that does

ANN. § 97-43-9 (West 1986) (providing a similar “baby” RICO statute to Hawaii’s with slightly different wording).

${ }^{256}$ Chevron Corp. v. Donziger, 833 F.3d 74 (2d Cir. 2016).

${ }^{257} \mathrm{Id}$. at 151 .

${ }^{258} I d$. at 137.

${ }^{259} I d$. at 138.

${ }^{260} \mathrm{Id}$.

${ }^{261}$ Chevron, 833 F.3d at 138.

262 The court's reasoning is that the definition of "person" found in 18 U.S.C. $\S$ 1961(3) applies only to "any individual or entity capable of holding a legal or beneficial interest in property." Id. (quoting § 1961(3)). Although the United States can own property, the defined term "person" in $\S 1964$ applies to plaintiffs and defendants alike, and with there being no indication that Congress intended to waive sovereign immunity for RICO claims, the United States cannot be a defendant. Id. Symmetry of interpretation of a term used more than once in a single statute thus demands that the United States cannot be a plaintiff, either. Id. (citing United States v. Bonanno Organized Crime Family, 879 F.2d 20, 21-27 (2d Cir. 1989) (affirming dismissal of the government's action brought under $\S 1964(\mathrm{c}))$ )). ${ }^{263}$ Chevron, 833 F.3d at 138. 
not exclude "relief that federal courts are authorized to grant under subsection (a)." ${ }^{264}$ Were it otherwise, logical absurdities would emerge: e.g., the Attorney General could obtain temporary-but not permanent-equitable relief. A more sensible reading, in the court's view, would be to limit the availability of temporary equitable relief to the United States and, "by parity of reasoning," to limit the availability of damages to a "person." 265 Along the way, the court made only passing reference to Wollersheim and nary a mention of legislative history, thus amplifying through silence the Seventh Circuit's position in $N O W$ that the statute is clear, so considering legislative history is an error. How is one to explain the Wollersheim-NOW divide?

\section{EXPLAINING INTERPRETIVE DISAGREEMENTS}

If the Realists were right that facts decide cases, then it's worth remarking that Wollersheim was a suit in which the Church of Scientology sought a RICO injunction barring a splinter church from disseminating allegedly stolen scriptural materials - hardly the sort of plaintiff or dispute within RICO's central zone of interest. ${ }^{266}$ The point is that sometimes courts choose particular interpretive techniques when they believe something along the line of, "it just can't be that this statute covers this claim." In such cases, an inquiry ensues, one typically cast in terms of a search for legislative "intent" or "purpose." We'll turn to a discussion of what those terms may mean in a minute, but let's start with a different question: What could make a judge predisposed to interpret RICO in a way that gives it an expansive criminal reach, on the one hand, and a narrow civil reach, on the other? The answer lies, I think, in a public narrative about the rise of organized crime in America and the government's moves to combat it. We find romanticized versions in this public narrative threaded through popular novels and films, from Little Caesar (whose antihero, Rico, may have given RICO its name), ${ }^{267}$

\footnotetext{
${ }^{264}$ Id. at $138-139$.

${ }^{265} \mathrm{Id}$. at 139.

${ }^{266}$ In anticipation of a point I'll reach in a minute, there are many instances in case law in which courts have tacitly adopted social narratives that distinguish "religions" from "cults." For example, in Minersville School District v. Gobitis, the plaintiffs challenged the school's requirement for students to salute the American flag. The Court described the plaintiffs' parents as being "possessed of conscientious scruples." See, e.g., Minersville Sch. Dist. v. Gobitis, 310 U.S. 586, 597 (1940). Whether that type of social narrative was at work in Wollersheim remains a matter for speculation. But, at least for me, that eventuality is not implausible.

${ }^{267}$ For decades, there has been speculation that the acronym "RICO" was a nod to Rico, the gangster protagonist of Little Caesar played by Edward G. Robinson. See LITTLE CAESAR (Warner Brothers 1931). For more on the relationship between the film and the statute, see Parnes v. Heinold Commodities, Inc., 548 F. Supp. 20, 21 n.1 (N.D. Ill. 1982); G. Robert Blakey \& Thomas A. Perry, An Analysis of the Myths That Bolster Efforts to Rewrite RICO and the Various Proposals for Reform:
} 
to the Godfather series, to Goodfellas, to more recent offerings like Boardwalk Empire. And we see the narrative explicitly at play in the deep background of legislative efforts to curb the influence of mobsters and the proliferation of their criminal acts. ${ }^{268}$

\section{A. Narratives: Large and Small}

Before getting to specifics, a few words explaining what I mean by "narrative" will sharpen the ensuing discussion. Narrative is a broad concept, one that is currently in such vogue that it loses explanatory significance without first defining some parameters. Here's what I have in mind: a narrative is (1) a selective appropriation of past events, evidence, and actors, (2) a temporal ordering of events and evidence that presents them with a beginning, middle, and end; and (3) an overarching structure that contextualizes these events and evidence as part of an opposition or struggle. ${ }^{269}$ Thus constituted, narratives exist on multiple planes, ranging from larger cultural narratives in which whole societies are invested to the individual narratives that we use to anchor ourselves in the world. Jonathan Hearn, following Margaret Somers, has developed a useful framework within which to examine narrative forms and how particular narratives interact. ${ }^{270}$ Both Hearn and Somers examine the narratives that individuals and groups participate in.

They identify several dimensions to narrativity, but I want to focus on the relationship between just two of them: ontological and public narratives. Ontological narratives are narratives that individuals use for making sense of their lives, sometimes by adopting existing ones. ${ }^{271}$ Hearn explains that this process often involves 'appropriating and customizing "public narratives": those narratives attached to cultural and institutional formations larger than the single individual. ${ }^{272}$

\footnotetext{
“Mother of God-IS This the End of RICO?”, 43 VAND. L. REV. 851, 984-87 (1990).

${ }^{268}$ I've recounted the legislative and larger contextual history of organized crime statutes in Of Gangs and Gaggles. Gordon, Gangs and Gaggles, supra note 1, at 977-79.

${ }^{269}$ RANDY GORDON, REHUMANIZING LAW: A THEORY OF LAW AND DEMOCRACY 41 (2011).

270 Jonathan Hearn, Narrative, Agency, and Mood: On the Social Construction of National History in Scotland, 44 COMP. STUD. SOC'Y \& HIST. 745 (2002);

Margaret R. Somers, The Narrative Constitution of Identity: A Relational and Network Approach, 23 THEORY \& SOC'Y 605 (1994).

${ }^{271}$ Gordon, supra note 269, at 44; see also Somers, supra note 267, at 618 ("These are the stories that social actors use to make sense of - indeed, to act in - their lives.").

${ }^{272}$ Hearn, supra note 267 , at 748 .
} 
Thus conceived, a public narrative might trace the ups and downs of families like the Kennedys; or the rise of America as a global power; or periods of widespread fear or prosperity. For example, a long string of commentators have observed that American identity is built around a "story of origins." 273 By this they mean "the story of the men, documents, and events that we celebrate on the Fourth of July" - the Founding Fathers, the Declaration, and the Constitution. The Constitution plays an especially important role in the narrative in that it solidifies "a frame of reference for understanding the 'Americanism' of people who regard themselves as American." Of course this story is as much a story of exclusion as inclusion and has fostered endless deconstructions unmasking the institutionalized hierarchies that undergird it. Our mission is not to wade into the critical stream flowing around that particular narrative but rather to emphasize that all interpreters come to an interpretive task invested in public narratives of one sort or another and those narratives color the lens through which the interpreter views the object of interpretation.

Bernard Jackson illustrates how social narratives come in to play in legal contexts, especially that of jury trials. ${ }^{274} \mathrm{He}$ starts from the premise that narrative is a major form of cultural communication and is the mode in which value judgments are stored and transmitted. Because of this, "[m]any of our value judgments are expressed through modes and degrees of approval or disapproval of narrativised models of action. Thus, the facts in a case are presented by the prosecution in the form of a story whose action is known to be disapproved, while the defence presents an alternative story, where the action is differently evaluate." 275 These stories that we all carry around should not be understood as being as detailed as plays or movie scripts but rather as basic structures capable of supporting a range of concrete scenarios. At trial, the successful advocates' craft is to hang selected facts onto an implicitly recognized narrative form that leads the jury to find facts and reach a verdict that weighs one way rather than another.

Of course lay jurors are not the only legal actors with a stock of social knowledge. So do judges. Jackson poses a problem of interpretation that is instructive: a historian of ancient law is examining a rule that he thinks he understands, and he undertakes to discover the "origins" of the rule. ${ }^{276}$ Is the rule derived from previous rules of the same system? Or is it a transplant from a foreign system? Making this determination entails application of a

\footnotetext{
${ }^{273}$ GARY MINDA, Crossing the Literary Modernist Divide at Century's End, in LAW AND LITERATURE 321, 325 (Michael Freeman \& Andrew D. E. Lewis eds., 1999).

${ }^{274}$ BERnARD S. JACKSON, LAW, FACT, AND NARRATIVE COHERENCE 61-88 (Roby: Deborah Charles,

1988).

${ }^{275} \mathrm{Id}$.

${ }^{276} I d$.
} 
methodology that relates the problem to general theories of how law develops. "But such methodological discussion should not conceal from us the fact that judgments on such matters are informed by narrative structures." 277 Our historian has a stock of narratives telling in one developmental way or the other (what Jackson calls the "semantic" level) and another suggesting scenarios under which one might expect success in persuading others that his evaluation of the problem is correct (the "pragmatic" level). The answer that he ultimately supplies to the question presented will thus be a consequence of what he believes about how the world operates and what he decides is the most efficacious way to present his conclusion.

A judge facing a novel question of statutory interpretation faces a challenge of the same order. What are the origins of this statute? Why does it exist? And, equally important, how do I justify my interpretation? As a working hypothesis, I want to suggest that a court may interpret a statute in keeping with a socially received public narrative regarding the statute's purpose and then justify that interpretation with a seemingly consistent narration of legislative history. With that hypothesis in mind, let's look at some elements of RICO's legislative history. After that, I'll return (as the just- posed questions suggest) to the notion of judge-as-historian.

\section{B. RICO's History}

As early as the 1940s, newspaper and magazine articles, as well as local crime commissions, warned that a national crime syndicate was seizing control of America's major cities. ${ }^{278}$ At the time, there were few federal options - and much appetite - for attacking organized crime. ${ }^{279}$ Taking up the challenge, Senator Estes Kefauver of Tennessee introduced a resolution in 1950 authorizing the Committee on the Judiciary to investigate interstate, organized criminal activities. ${ }^{280}$ This committee ultimately issued four reports, which confirmed the existence of criminal syndicates and their pattern of corrupting state and local government. ${ }^{281}$ But the committee's proposed legislative solutions went nowhere at the time. ${ }^{282}$

The story picks up again in earnest in 1967 with the report of the President's Commission on Law Enforcement and Administration of Justice

\footnotetext{
${ }^{277} I d$. at 168 .

${ }^{278}$ Guide to Senate Records: Ch. 18 1946-68, NAT'L ARCHIVES, http://www.archives.gov/legislative/guide/senate/chapter-18-1946-1968.html (last visited Aug. 12, 2017).

${ }^{279} I d$.

${ }^{280} \mathrm{Id}$.

${ }^{281} \mathrm{Id}$.

${ }^{282} \mathrm{Id}$.
} 
(popularly known as the Katzenbach Commission). ${ }^{283}$ This report memorializes the public narrative that was then gelling around the social problems attributable to organized crime. As President Nixon told Congress, "[O]rganized crime has deeply penetrated broad segments of American life. In our great cities, it is operating prosperous criminal cartels. In our suburban areas and smaller cities, it is expanding its corrosive influence." 284 The problem was essentially threefold. First, organized criminals have a "virtual monopoly of illegal gambling, the numbers racket, and the importation of narcotics." ${ }^{285}$ Second, the proceeds of these illicit acts give these criminals the power and resources to underwrite criminal businesses like loansharking, to "infiltrate and corrupt organized labor," and to increase "its enormous holdings and influence in the world of legitimate business."286 Third, although "the 26 families of La Cosa Nostra" had been subject to multiple prosecutions, "not a single one of the 24 Cosa Nostra families have been destroyed" and the Mafia chieftains had "been notoriously successful in 'getting off' even in those relatively few cases in which the evidence has warranted the prosecution." 287 To ameliorate this situation, anti-racketeering hawks offered

a bill which has been carefully drafted to cure a number of debilitating defects in the evidence-gathering process in organized crime investigations, to circumscribe defense abuse of pretrial proceedings, to broaden Federal jurisdiction over syndicated gambling and its corruption where interstate commerce is affected, to attack and to mitigate the effects of racketeer infiltration of legitimate organizations affecting interstate commerce, and to make possible extended terms of incarceration for the dangerous offenders who prey on our society. ${ }^{288}$

This bill, which found final expression in the Organized Crime Control Act of 1970, aimed to cure "defects" in existing law of the sort we just reviewed. ${ }^{289}$ Accordingly, eight titles of the OCCA deal with the difficulties associated with prosecuting members of organized crime, one

\footnotetext{
${ }^{283}$ See Gerard E. Lynch, RICO: The Crime of Being a Criminal, Parts I \& II, 87 COLUM. L. REV. 661, 666 (1987) ("The legislative history of RICO begins with the report of the President's Commission on Law Enforcement and Administration of Justice (the Katzenbach Commission) in 1967.").

${ }^{284}$ S. Doc. No. 91-617 (1969) (quoting H.R. Doc. No. 91-105, at 1-3 (1969)).

${ }^{285} \mathrm{Id}$.

${ }^{286} \mathrm{Id}$.

287116 CONG. REC. 585-86 (1970).

${ }^{288} \mathrm{Id}$. at 585.

${ }^{289}$ See id. (discussing various issues related to organized crime and the inability to effectively prosecute such individuals responsible but insulated from liability).
} 
federalizes criminal law relating to illegal gambling, ${ }^{290}$ one creates a commission to evaluate the effectiveness and constitutionality of federal criminal laws and practices, ${ }^{291}$ one deals with explosives (a late addition with little apparent connection to the rest of the act), ${ }^{292}$ and one, Title IX, is RICO. ${ }^{293}$

If we set the crime-commission and legislative-committee crime reports from the mid-to-late 1960s alongside the OCCA, we see that the major objects of concern repeatedly articulated in the reports-prosecution difficulties, illegal gambling, andinfiltration of legitimate businesses - map quite nicely onto the structure of the OCCA. With respect to Title IX, as of January 21, 1970, it was entitled "Corrupt Organizations" and said to "[p]rohibit[] infiltration of legitimate organizations by racketeers or proceeds of racketeering activities where interstate commerce is affected[, and] [a]uthorize[] civil remedies comparable to anti-trust to prevent violation of law by divestiture, dissolution or reorganization." 294 Plenty of other legislative materials echo this anti-infiltration theme: "Section 1962 establishes a threefold prohibition aimed at stopping the infiltration of racketeers into legitimate organizations." ${ }^{295}$ Title IX "has as its purpose the elimination of the infiltration of organized crime and racketeering into legitimate organizations operating in interstate commerce." 296

In this respect, then, RICO is in sync with the public narrative as expressed in the various legislative and crime-commission reports and executive branch commentary. This could mean that RICO's purpose may be narrower than one might assume. No one doubts that its net is fine enough to catch groups other than the Mafia (e.g., Hell's Angels or the Irish Mob) ${ }^{297}$ i.e., it's not just an anti-Mafia statute. ${ }^{298}$ There's good reason, though, to think that despite the relatively narrow scope of RICO within the larger OCCA, its new remedies would attack the roots of organized criminal organizations and prevent their regeneration. Remember, despite the best efforts of prosecutors,

\footnotetext{
${ }^{290}$ Organized Crime Control Act of 1970, Pub. L. No. 91-452, 84 Stat. 922, 936-40 (codified at 18 U.S.C. $\S 1955$ (2006)).

${ }^{291} I d$. at 960.

292116 CONG. REC. S952 (1970) (codified at 18 U.S.C. $\S 841-848$ (2006)).

${ }^{293} I d$. at 941 (codified at 18 U.S.C. $\S \S 1961-1968$ (2006)).

${ }^{294}$ S. REP. NO. 91-617, at 591 (1969).

${ }^{295}$ H.R. REP. NO. 91-1549, at 57 (1970).

${ }^{296}$ S. REP. NO. 91-617, at 76 (1969) (expressing concern about "subversion of legitimate organizations," "infiltration of legitimate businesses," and "takeover of legitimate unions").

${ }^{297} 116$ CONG. REC. 503, 586 (1970).

${ }^{298}$ Although the idea was abandoned on Constitutional grounds, there was discussion in the House about creating a status offense based on membership in the Mafia. See Bennett v. Berg, 685 F.2d 1053, 1063 (1982) (discussing legislative history and congressional intent); see also Anza v. Ideal Steel Supply Corp., 547 U.S. 451, 471-74 (2006) (Thomas, J., dissenting) (internal citations omitted).
} 
"[n] ot a single one of the "families' of La Cosa Nostra has been destroyed."299 So one aim of RICO was to "remove the leaders of organized crime from their sources of economic power." 300 "Instead of their positions being filled by successors no different in kind, the channels of commerce can be freed of racketeering influence." 301

There is thus a non-frivolous argument that the courts were wrong to extend RICO's reach beyond the corruption and infiltration of legitimate organizations. But as infomercial hosts inevitably say in hawking their products, "That's not all!" For as the passages we just reviewed show, there are plainly references in the legislative history to RICO having a broad "commercial" purpose. For example, as late as July 1970, legislative materials continued to stress the analogy to antitrust law: "Title IX, dealing with racketeer influenced and corrupt organizations, was modeled on the [American Bar Association's] 1968 resolution endorsing 'in principle' all legislation having as its purpose 'the adopting of the machinery of antitrust laws to the prosecution of organized crime." 302 And as Justice Thomas emphasized in his Anza dissent, Congress was concerned about the illegitimate competitive advantage that racketeers had over their legitimate rivals:

The sponsor of a Senate precursor to RICO noted that "the evil to be curbed is the unfair competitive advantage inherent in the large amount of illicit income available to organized crime." Upon adding a provision for a civil remedy in a subsequently proposed bill, Senator Hruska noted: "[This] bill also creates civil remedies for the honest businessman who has been damaged by unfair competition from the racketeer businessman. Despite the willingness of the courts to apply the Sherman Anti-Trust Act to organized crime activities, as a practical matter the legitimate businessman does not have adequate civil remedies available under that act. This bill fills that gap." A portion of these bills was ultimately included in RICO, which was attached as Title IX to the Organized Crime Control Act. The Committee Report noted that the Title "has as its purpose the elimination of the infiltration of organized crime and racketeering into legitimate organizations operating in interstate commerce." The observations of the President's Commission on Law Enforcement and Administration of Justice, the source of much of the congressional concern over organized crime, are consistent with these statements.

\footnotetext{
${ }^{299}$ S. REP. NO. 91-617 at 45 (1969).

${ }^{300} \mathrm{Id}$. at 80 .

${ }^{301} \mathrm{Id}$.

302116 CONG. REC. 25190 (1970).
} 
Its chapter on organized crime noted that "organized crime is also extensively and deeply involved in legitimate business . . . [ [I]t employs illegitimate methodsmonopolization, terrorism, extortion, tax evasion - to drive out or control lawful ownership and leadership and to exact illegal profits from the public." The report noted that "[t]he millions of dollars [organized crime] can throw into the legitimate economic system gives it power to manipulate the price of shares on the stock market, to raise or lower the price of retail merchandise, to determine whether entire industries are union or nonunion, to make it easier or harder for businessmen to continue in business." 303

So, at a minimum, there's a tension in RICO's legislative history on the related questions of RICO's civil reach and its relationship to the antitrust laws. More specifically, was the language of $\S 4$ of the Clayton Act selected because it was a handy articulation of the causation standard necessary to invest a private litigant with standing to pursue an otherwise criminal violation? Or did this selection signal that the antitrust and RICO acts were to work in tandem? Both? It's hard to say, but the questions throw us onto the crisscrossing paths of two teleological inquiries. First, what's the relationship between the words of the statute and what the adopters of those words hoped to accomplish with them? Second, how is one to reconcile RICO's potential as a powerful prosecutorial weapon with a general reluctance to federalize plain-vanilla commercial and consumer claims? What we will find, I think, are context-specific formulations of RICO's "intent" or "purpose" that are observable when courts narrate RICO's legislative history.

\section{What's Intent?}

When we ponder the point of a statute, the usual approach is to talk about "legislative intent" or "statutory purpose," labels that bleed into one another and that are often disputed. ${ }^{304}$ Some observers posit "intent" as conceptually narrow (the "idea she sought to transfer using the words she chose to speak") and "purpose" as broad ("what a legislator imagines or hopes will change about the world by means of enacting the legislation"). ${ }^{305}$ As I've suggested before, on this view, the intent of RICO might be framed as "locking up people who invest in, muscle in on, or operate enterprises

\footnotetext{
${ }^{303}$ Anza, 547 U.S. at 473-74 (Thomas, J., dissent) (alterations and emphasis in original).

${ }^{304}$ For a helpful survey of the various positions, see Abby Wright, For All Intents and Purposes: What Collective Intention Tells Us about Congress and Statutory Interpretation, 154 U. PA. L. REV 983 (2006).

${ }^{305}$ See Id. at 991-92 (discussing a distinction between intent and purpose).
} 
through a pattern specified racketeering acts." 306 The purpose of RICO, by contrast, might be framed more broadly, perhaps something like "helping destroy organized crime in the United States." 307 Now whether Congress is too complex a social group to have "intents" and "purposes" in a strong sense is a debate that has raged for decades. ${ }^{308}$ But we're not going to get ensnared in this debate or in disputes over terminology: what we're interested in is how courts ascribe an intent to Congress or a purpose to legislation ${ }^{309}$

In MacCormick's view, the "value-based and teleological character" of statute obliges an interpreter to consider what values and aims "should be postulated as the telos or end imputed to legislation." 310 So a rounded interpretive theory must mark that legislating "is a rational and teleological activity guided by political programmes structured by some sense of justice and the common good." 311 Quite naturally, then, interpreters make use of information about the circumstances of particular legislative acts:

[T] hese include commission reports, committee papers, and the like which identify a mischief and propose possible remedies for it. The "intention of parliament" plays a proper role in legislative interpretation, but not because there is a discoverable state of somebody's mind that can with special authenticity explain the words used as bearing the meaning attested by that mental state. On the contrary, it is because the legislature makes a practice of legislating in English of a particular register; because rational acts of legislation hang together in a coherent way internally and in relation to the

\footnotetext{
${ }^{306}$ Gordon, Gangs and Gaggles, supra note 1, at 1024.

${ }^{307} \mathrm{Id}$. ("Plainly, undertaking this exercise will not generate single definitive formulations of intents and purposes.")

${ }^{308}$ See Gutierrez-Brizuela v. Lynch, 834 F.3d 1142, 1153 (10th Cir. 2016) (“Trying to infer the intentions of an institution composed of 535 members is a notoriously doubtful business under the best of circumstances."); see also Wright, supra note 304, at 1007-24. The gist of Wright's argument is that Congressional intent can be divined with respect to particular legislation because of how Congress is structured and the procedures it follows. This is so even though we know that individual legislators may not have carefully considered a bill, might be hostile to it, and may have voted for it for horsetrading reasons. But inferring purpose in the broadest sense requires resort to extrinsic reasons, which renders any conclusions suspect. Even though Wright believes that Congress is not an entity capable of forming purposes, she ultimately states that many arguments based on "purpose" are really mislabeled "intent" arguments. Id. at 1024. Thus said, my proffered statement of RICO's purpose may really be an "intent."

${ }^{309}$ See Lawrence M. Solan, Private Language, Public Laws: The Central Role of Legislative Intent in Statutory Interpretation, 93 GEO. L.J. 427, 453 (2005) [hereinafter Private Language].

${ }^{310}$ MACCORMICK, supra note 9, at 134.

${ }^{311} \mathrm{Id}$.
} 
rest of the legal system; and because reforms aim to remedy sensibly some identified deficiency; that one can finally impute to the legislature an intention that certain words be understood with a certain meaning rather than another one that they might bear. "Intention" is a rhetorically effective and legitimate way to frame a conclusion about what is the most reasonable interpretation in context, not a further argument to that effect. ${ }^{312}$

At a very high level of generality, there is no dispute that Congress "intended" RICO to help root out organized crime. But at more particular levels, there's much room for genuine argument. What makes "organized" crime organized?" What do "organized" criminals do? In answer to the first question, we know that there would be something of a consensus when talking about the paradigmatic case of the Mafia, a group with initiation rites, membership criteria, a strictly hierarchical structure, and so forth. Until Boyle, most courts held that an association-in-fact enterprise within RICO's reach had to share at least some of these characteristics. But Boyle, which involved a loosely affiliated and shifting group of bank robbers, moved the needle far down the organizational spectrum from the Mafia pole. ${ }^{313}$ So by the time we layer on the full range of illegal acts that criminal organizations undertake (which include items as disparate as providing illegal goods and services, murdering rivals, bribing public officials, investing dirty money in legitimate businesses, muscling in on unions, loansharking, hijacking, fraudulent schemes and more), ${ }^{314}$ we're already dealing with a serious

${ }^{312} I d$. at 137 . Solan writes to similar effect:

$[\mathrm{L}]$ aws are written in language and language can only be understood in context. The thinking of those who supported and proposed the law in the first place may not reflect the will of every legislator, but it can certainly make some contribution to statutory interpretation if used wisely. At the very least, it can help us to determine whether the difficulty in applying the statute results from an unfortunate choice of statutory language to effect a legislative goal that becomes clear once one investigates the matter. And it can be used to confirm that decisions made on other grounds are not likely to fly in the face of what the statute was intended to accomplish.

Private Language, supra note 309, at 435.

${ }^{313}$ Boyle v. United States, 556 U.S. 938, 941 (2009).

${ }^{314}$ For an overview of what organized criminals do, see Lynch, supra note 283, at, 669-70. Indeed, the initial part of the definition of "racketeering activity" in $\S 1961$ signals hard-core criminal acts: "any act or threat involving murder, kidnapping, gambling, arson, robbery, bribery, extortion, dealing in obscene matter, or dealing in a controlled substance or listed chemical (as defined in section 102 of the Controlled Substances Act), which is chargeable under State law and punishable by imprisonment for more than one year ...." If the "fraud" predicate acts were 
interpretive dilemma in the context of a statute that's vague to begin with ${ }^{315}$ and that's been construed in ways that have made the matter rather worse. ${ }^{316}$

It should come as no surprise, then, that a judge trying to make sense of a civil RICO claim will form a view as to RICO's purpose, and that view is likely steeped in the pervasive public narrative that we've been discussing. ${ }^{317}$ This means that - at the personal, ontological level-a judge will analyze RICO according to the constraints of that public narrative. She will thus interpret RICO so as to ensure its potency as a prosecutorial weapon but also - as a collateral matter-assume that the civil dimension of the statute isn't intended to apply to conduct that doesn't look like gangland conduct - unless she is in thrall to an overriding theoretical construct (e.g., strict textualism) that acknowledges the dominant narrative but nonetheless rejects it because Congress (perhaps foolishly) chose language broader than its stated purpose required. ${ }^{318}$ This brings us to our final point: how

stripped out of the statute, it's hard to imagine many civil RICO suits against legitimate businesses as defendants.

${ }^{315}$ For a discussion on the potential constitutional weaknesses and vagueness of RICO's definition and application, see George Clemon Freeman, Jr. \& Kyle E. McSlarrow, RICO and the Due Process "Void for Vagueness" Test, 45 BUS. LAW. 1003, 1008-10 (1990); Michael S. Kelley, "Something Beyond": The Unconstitutional Vagueness of RICO's Pattern Requirement, 40 CATH. U. L. REV. 331, 380-94 (1991); Jed S. Rakoff, The Unconstitutionality of RICO, N.Y. L.J., Jan. 11, 1990, at 3; Terrance G. Reed, The Defense Case for RICO Reform, 43 VAND. L. REV. 691, 721-27 (1990); H.J. Inc. v. Nw. Bell Tel. Co., 492 U.S. 229, 255 (1986) (Scalia, J., concurring) (criticizing the majority's opinion as "increas[ing] rather than remov[ing] [RICO's] vagueness").

316 See Antonio J. Califa, RICO Threatens Civil Liberties, 43 VAND. L. REV. 805, 815-17 (1990) (noting that legislative history reflects congressional intent to limit RICO's application, but these limits have been minimized through expansive judicial interpretation); Barry Tarlow, RICO Revisited, 17 GA. L. REV. 291, 294 (1983) ("[S]ome judges . . have strained to adopt broad constructions of RICO" with the result that "the scope of the RICO statute has been expanded far beyond what was intended by Congress.").

317 See generally, N. ALLOTT \& B. SHAER, Legal Speech and the Elements of Adjudication, in THE NATURE OF LEGAL INTERPRETATION 194 (Brian Slocum, ed., 2017).

${ }^{318}$ See Anza v. Ideal Steel Supply Corp., 547 U.S. 451, 473-74 (2006)(Thomas, J., dissent)

Justice Thomas argued that the Court's majority limited the lawsuits that may be brought under the civil enforcement provision of the Racketeer Influenced and Corrupt Organizations Act (RICO or Act), 18 U.S.C. $§ 1961$ et seq. (2000 ed. and Supp. III), by adopting a theory of proximate causation that is supported neither by the Act nor by our decision in Holmes . . ., on which the Court principally relies. The Court's stringent proximate-causation requirement succeeds in precluding recovery in cases alleging a violation of $\S 1962$ (c) that, like the 
legislative history can be (re)constructed in ways that nudge it into phase with the "gangster" social narrative and thereby make legislative purpose seem self-evident.

Victoria Nourse has articulated a sensible way of thinking about legislative history, its uses, and its relationship to notions of legislative intent and purpose. ${ }^{319}$ She frames her discussion within a decades-old debate between textualists and purposivists and suggests that neither group adequately defines what it means by "legislative history," which has reduced the utility of what happens in the legislative process to an all-or- nothing proposition. ${ }^{320}$ First, she draws distinctions among statutory history (the evolution of the text of a statute as it meanders through the process), statutory usage (the semantic content of the text as commonly understood by legislators), and public documents bearing institutional sanction (e.g., committee reports). ${ }^{321}$ So instead of legislative "history," she asks us to consider legislative "context," in all these various forms. ${ }^{322}$

Second, she debunks the notion (the origin of which she associates with the Realist Max Radin) that legislatures can't have "intents" or "purposes." ${ }^{23}$ Here, too, she suggests a change in nomenclature, preferring to focus instead on legislative "decisions." 324 This is actually more than a change in diction because it suggests that a focus on particular moments of decision will yield insights superior to those generated after "roaming around" in legislative materials without due regard to legislative procedures. $^{325}$ To do otherwise, she suggests, increases the risk of "fantasy narratives" that "impos[e] coherence on a tale never meant to be coherent." 326

I don't read her to say, though, that the "zigs and zags" of the legislative process somehow render legislative history unnarratable. Of course it can be narrated (as can the history of anything): this happened, then that happened, then some other things happened, then the bill finally passed into law. And this narrative need not be strictly linear, either: zigging and zagging through time is a hallmark of the Modernist novel. Indeed, Gerard Genette's (a literary theorist whom Nourse cites) masterwork, Narrative Discourse, is an attempt to chart the temporal flows and eddies of Marcel

present one, have nothing to do with organized crime, the target of the RICO statute.

${ }^{319}$ Victoria Nourse, Elementary Statutory Interpretation: Rethinking Legislative Intent and History, 55 B.C. L. REV. 1613 (2014).

${ }^{320}$ Id. at $1614-1615$.

${ }^{321} I d$. at 1616 ("Both textualism and purposivism are poorer for failing to parse these different meanings of legislative history.").

${ }^{322} I d$. at 1616.

${ }^{323} \mathrm{Id}$. at 1621-25.

${ }^{324}$ Nourse, supra note 318 at 1621-1625.

${ }^{325} \mathrm{Id}$. at 1648-50.

${ }^{326} \mathrm{Id}$. at 1649. 
Proust's Search for Lost Time. ${ }^{327}$ All Nourse "intends" to say, I think, is that courts shouldn't narrate legislative history (1) without an eye to legislative process and an understanding of what is important and what is trivial and (2) by cherry-picking zigs and zags and thereby creating what amounts to fiction, in the sense of unfairly representing "what really happened."

Yet the question remains, why do courts so often resort to legislative history as an interpretive aid? The answer, I think, lies in the nature of narrative. All historical narratives are, as I've argued before, partial in both senses, and the result of selective appropriation of evidence and events. But a coherent narrative can carry great rhetorical - and in the context of a legal decision, justificatory - weight. Indeed, there's a good argument to be made that the coherence of a narrative and its plausibility (and attendant rhetorical success) are closely related. ${ }^{328}$ So it's no surprise that a judge who comes to the moment of decision with a preconception of a statute's purpose would narrate that statute's history in a way that unerringly demonstrates that purpose and only that purpose. What's interesting here is not that the use of legislative history is more pernicious than other interpretive tools; it's just that a close reading of the narrative construction, the selective appropriation, reveals traces of the pre-judgment that guided the selection of legislative evidence to establish a fact of the matter.

Legal narratives, which include narrations of legal history, are not different in kind from other types of narratives; to the degree they are different, it is only because they are made according to a particular set of conventions, a point that Ian Watt made long ago in examining the contours of the "realistic" novel. ${ }^{329}$ Does a conventional formula lead to truth, to a fact of the matter? Suffice it to say that Watt sees it as an open question ("formal realism is, of course, like the rules of evidence, only a convention"), ${ }^{330}$ and Jackson sees even greater potential problems ("the construction of fact in the courtroom is comparable to the construction of plausibility of much narrative fiction."). ${ }^{331}$ So we need to proceed cautiously.

\footnotetext{
${ }^{327}$ Gerard Genette, NARrative Discourse: An Essay In Method (Jane E. Lewin trans., Cornell Univ. Press 1983). In an analysis of a passage from Proust's abandoned novel, Jean Santeuil, Genette describes the temporal positions as "a perfect zigzag." Id. at 38.

${ }^{328}$ See JACKSON, supra note 278, at 73 (discussing Bennett and Feldman's account of fact construction).

${ }^{329}$ Ian Watt, Realism and the Novel Form, in LAW AND LiTERATURE 463, 463-64 (Lenora Ledwon ed., 1996).

${ }^{330} I d$. at 464.

${ }^{331}$ See JACKSON, supra note 278, at 73.
} 
When we speak of legislative history and whether it can conclusively establish a fact-of-the-matter, Paul Veyne's description of how all history is (re)constructed seems apt. In his view,

History is an account of events: all else flows from that. Since it is a direct account, it does not revive, any more than the novel does. The actual experience, as it comes from the hands of the historian, is not that of the actors; it is a narration, so it can eliminate certain erroneous problems. Like the novel, history sorts, simplifies, organizes, fits a century into a page. This synthesis of the account is not less spontaneous than that of our memory when we call to mind the last ten years through which we have lived. ${ }^{332}$

History is a synthesis and a condensation; furthermore, it is tainted by perspective: it is not unmediated "fact" and this is so even for direct actors, whose memories and perceptions are never more than partial:

To speculate on the interval that always separates the actual experience and the recollection of the event would simply bring us to see that Waterloo was not the same thing for a veteran of the Old Guard and for a field marshal; that the battle can be related in the first or third person; that it can be spoken of as a battle, as an English victory, or as a French defeat; that from the start one can drop a hint of the outcome or appear to discover it. These speculations can produce amusing experiments in aesthetics; to the historian, they are the discovery of a limit. ${ }^{333}$

Legislative history-because it is history-is a present reconstruction of past events. It thus suffers from the same limitations as all history: it is based on an incomplete record, which could have been manipulated at the time; it can be manipulated or distorted through present acts of interpretation; and, most important, it is a narrative. On this view, even though Professor Blakey - or any other "insider" for that matter - may have had a privileged vantage from which to observe (and perhaps shape) the birth of RICO, his is still only $\boldsymbol{a}$ perspective, and an inevitably limited one at that: ${ }^{334}$

\footnotetext{
332 PAul Veyne, Writing History: Essay on Epistemology 4 (Mina MooreRinvolucri trans., Wesleyan Univ. Press 1984).

${ }^{333} I d$.

${ }^{334}$ Professor Blakey was Chief Counsel to the Subcommittee on Criminal Laws and Procedures of the United States Senate Committee on the Judiciary "when the Subcommittee processed the legislation that became RICO in 1969 and 1970." Brief for G. Robert Blakey as Amici Curiae, supra note 252.
} 
That limit is that in no case is what historians call an event grasped directly and fully; it is always grasped incompletely and laterally, through documents or statements, let us say through tekmeria, traces, impressions. Even if I am a contemporary and a witness of Waterloo, even if I am the principal actor and Napoleon in person, I shall have only a perspective of what historians will call the event of Waterloo; I shall be able to leave to posterity only my statement, which, if it reaches them, they will call an impression. Even if I were Bismarck deciding to send the Ems dispatch, my own interpretation of the event would perhaps not be the same as that of my friends, my confessor, my regular historian, and my psychoanalyst, who may have their own version of my decision and think they know better than I do what it was I wanted. In essence, history is knowledge through documents. Thus, historical narration goes beyond all documents, since none of them can be the event; it is not a documentary photomontage, and does show the past "live, as if you were there." 335

In the context of civil RICO, these problems are especially acute because "RICO's legislative history is more ambiguous than the statute." 336 Thus, depending on the issue to be argued, a sophisticated advocate can state that, on the one hand, (1) "the antitrust analogy is unpersuasive, since it does not take into account the significant structural and language differences between the antitrust statutes and civil RICO" and "a reading of civil RICO in light of the lawyers' fallacy, which mistakenly believes that the same words have the same meaning without regard to context of time and place,"337 and, on the other hand, that (2) through "RICO's model in the anti-trust laws ..., Congress in 1970 achieved a remarkable integration between the antitrust statutes and RICO in protecting the free market place." ${ }^{338}$ This confirms, at least with respect to RICO, that citing legislative history is like "looking over a crowd and picking out your friends"- the qualification being that your friends may change from time to time. ${ }^{339}$ So, as we saw in Wollershein, the court "picked out some friends" and narrated RICO's legislative history in a way that justified its refusal to extend the benefits of RICO to an outlier religious organization on what seemed like, at best, a misappropriation claim of some sort.

\footnotetext{
335 VEYNE, supra note 334, at 4-5.

${ }^{336}$ Blakey \& Cessar, supra note 30, at 549.

${ }^{337} \mathrm{Id}$. at $554-555$.

${ }^{338}$ Brief for G. Robert Blakey as Amici Curiae, supra note 252, at 8-9.

${ }^{339}$ Patricia M. Wald, Some Observations on the Use of Legislative History in the 1981 Supreme Court Term, 68 IOWA L. REV. 195, 214 (1983) (referring to an oftquoted observation of Judge Harold Leventhal).
} 


\section{CONCLUSION}

In his landmark Legal Reasoning and Legal Theory, Neil MacCormick opens the final chapter by quoting the bit from Gulliver's Travels in which the Lilliputians describe in meticulous detail the "wonderful kind of engine" hanging from a "great Silver Chain" attached to Gulliver's waistcoat. We know this to be a watch, but the Lilliputians don't have the requisite "social knowledge" to know what the "engine" is for. This Article suggests that judges have - in addition to legal knowledge-_"social knowledge" that they consciously or unconsciously draw upon in performing the act of judging. And they do so inevitably, as do all humans. This is not a "problem" to be "solved" but rather an observation that should cue readers of judicial opinions to search for textual clues that may reveal the underlying beliefs that are informing - in some cases driving - the decision in any particular case. Unlike the Lilliputians who can "read" Gulliver only from an external perspective, we can assume an internal perspective and see "what's really going on." 